University of Louisville

ThinkIR: The University of Louisville's Institutional Repository

Electronic Theses and Dissertations

$5-2018$

\title{
African American grandmothers as the black matriarch : you don't live for yourself.
}

Tanisha Nicole Stanford

University of Louisville

Follow this and additional works at: https://ir.library.louisville.edu/etd

Part of the African American Studies Commons, Other Feminist, Gender, and Sexuality Studies Commons, and the Women's History Commons

\section{Recommended Citation}

Stanford, Tanisha Nicole, "African American grandmothers as the black matriarch : you don't live for yourself." (2018). Electronic Theses and Dissertations. Paper 2944.

https://doi.org/10.18297/etd/2944

This Master's Thesis is brought to you for free and open access by ThinkIR: The University of Louisville's Institutional Repository. It has been accepted for inclusion in Electronic Theses and Dissertations by an authorized administrator of ThinkIR: The University of Louisville's Institutional Repository. This title appears here courtesy of the author, who has retained all other copyrights. For more information, please contact thinkir@louisville.edu. 


\title{
AFRICAN AMERICAN GRANDMOTHERS AS THE BLACK MATRIARCH: YOU DON'T LIVE FOR YOURSELF
}

\author{
By \\ Tanisha Nicole Stanford \\ B.S., University of Houston, 2016
}

\begin{abstract}
A Thesis
Submitted to the Faculty of the College of Arts and Sciences of the University of Louisville in Partial Fulfillment of the Requirements for the Degree of
\end{abstract}

Master of Arts in Pan-African Studies

Department of Pan-African Studies

University of Louisville

Louisville, Kentucky

May 2018 
Copyright 2018 by Tanisha Nicole Stanford

All rights reserved 



\title{
AFRICAN AMERICAN GRANDMOTHERS AS THE BLACK MATRIARCH: YOU
}

DON'T LIVE FOR YOURSELF

\author{
By \\ Tanisha Nicole Stanford \\ B.S., University of Houston, 2012 \\ A Thesis Approved on
}

April 16, 2018

by the following Thesis Committee:

Dr. Theresa Rajack-Talley

Dr. Latrica Best

Dr. Kaila Story 


\title{
DEDICATION
}

This thesis is dedicated to my grandmothers

\author{
Lois Marie Stanford \\ and \\ Lilian Pauline Bunton
}

May they continue to guide me and watch over me in spirit 


\section{ACKNOWLEDGMENTS}

I would like to thank my professor and thesis chair, Dr. Rajack-Talley for her guidance and patience. Further, I would like to show appreciation to my other committee members, Dr. Best and Dr. Story for being flexible with me as figured out specific topics and dates. Most importantly, I'd like to thank my family, my mother, Bernadette, my father, Arthur W., sister, Tiara, my grandfather, Arthur L., as well as all of my other family for supporting me in my academic journey and encouraged me to continue my research when I was emotional for the loss of my own grandmothers. Lastly, I'd like to thank my cohort, LeAnna, Janea and Amber for being a constant support system for me. 


\section{ABSTRACT \\ AFRICAN AMERICAN GRANDMOTHERS AS THE BLACK MATRIARCH: YOU DON'T LIVE FOR YOURSELF \\ Tanisha Nicole Stanford \\ May 12, 2018}

This study examined historical and contemporary roles of African American grandmothers within the familial system, and their socio-psychological experiences. The primary method of data collection was semi-structured, conversational style interviews with an oral history aspect. There were six grandmothers interviewed, two from the midwest region of the United States, and four from the southern region. The findings reveal stories that corroborate with the literature on the role of women in African American families and that of the Black matriarch, considering their strength are not inherent but necessary. They are not born matriarchs or strong black women, they become that person within the black family structure and circumstances. Key findings suggest that the roles and responsibilities of the grandmothers were similar to that of their own mother and grandmothers, as well as some of the historical roles that black women played in white and black families. 
TABLE OF CONTENTS

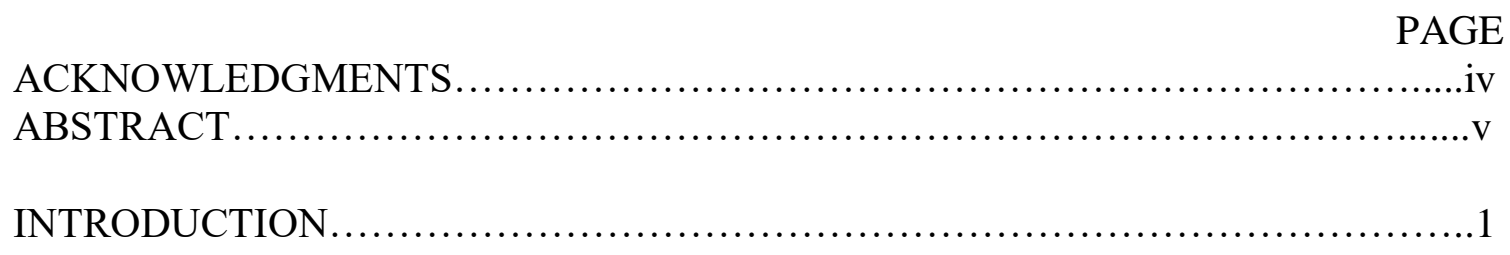

THE MAMMY, THE MATRIARCH AND THE GRANDMOTHER..................13

THEORETICAL FRAMEWORK-BLACK FEMINIST THOUGHT .................28

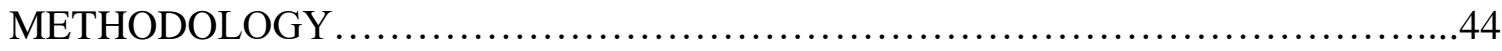

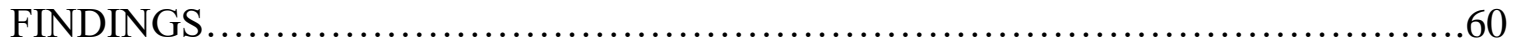

SUMMARY, DISCUSSION \& CONCLUSION .................................. 82

REFERENCES............................................................ 89

CURRICULUM VITA........................................................ 95 


\section{CHAPTER 1: INTRODUCTION}

\section{Background}

The black family structures in America have been studied from a myriad of theoretical frameworks in search of deeper understandings of their historical and contemporary experiences. Scholars have studied black people's experiences from the pre-transatlantic slave trade, during the middle passage, within slavery, post emancipation, throughout the Jim Crow era, post-civil rights and black power movement, contemporary trends, as well as futuristic possibilities for African American families. Just as the social climate changes throughout these different eras, the African American family also changes and adapts for the sake of the survival and improved living conditions of their families and communities. Andrew Billingsley even considered African American people to be the, “... most resilient and adaptive people.” He even goes on further to suggest that the African American familial experience varies with regards to historical period, region and other circumstances (pg. 38, 1968).

Unfortunately, many studies regarding the history of the black family have focused primarily on labeling what they believe as pathological characteristics. While it is important to acknowledge some of the adaptive behavior to socio-economic circumstances that exist within the black family, it is even more critical to address the 
causes of the behaviors as well as the cultural strengths and traditions that help promote progression and survival of the African American family. Foster, (pg. 231, 1983) asserts that by concentrating on the constructiveness and stamina within the black families, research could potentially provide solutions for future worries that may arise.

Moreover, the survival of the black family heavily depends on its ability to change, grow, and branch out when need be. The complexities and continuous evolution of the black family is an astonishing and intriguing phenomenon. Willie and Reddick go so far as to suggest that the history of the black family should be considered a "miraculous movement" (pg. 5, 2010). Even with social, psychological, economic, cultural and other systemic barriers, the black family continues to defy the odds and adapt to the social climate of the times. "Furthermore, due to some African Americans' lower economic position in society, their families have developed alternative family forms as mechanisms for survival" (Littlejohn-Blake \& Darling, pg. 461, 1993). Thus, black families can fall anywhere within SES and class ranks, traditional or nuclear families, single-mother headed, single-father headed, grandparent headed, same sex, etc., while negotiating and navigating through different yet similar forms of oppression. McAdoo states, "Never before has it been more obvious that there is not just one reality of the black experience" (pg. 18, 1998). Though all periods of evolution and structural change in the black family is critical in understanding what the future looks like for black families, in this introduction, the different SES in black families, as well as single-mother and grandparent lead households will be explored.

Take for example two-parented, middle-class African American families. Many may make the assumption that this particular family set is fully integrated into 
mainstream society; they are the closest to what may be considered a traditional family. Historically, all black families have seemed to strive for typical middle class social and political achievements. These achievements include receiving bachelor's degrees and higher, as well as pushing their children to do so; obtaining occupations such as doctors, lawyers, professors, etc.; and securing home ownership. (Willie \& Reddick, pg. 23, 2010) Regardless of these achievements, these families still experience oppression in various ways that challenge their family structure. Given their immersion into white mainstream culture, one of their primary challenges could be that they are often the only or one of few persons of color in their jobs, communities, and schools (Franklin \& James, 2015). Thus, challenging the emotional or psychological wellbeing of middle-class black people due to microaggressions, isolation, repression and suppression, and their children could possibly even be bullied for their minority status; which further causes strain on their middle-class family life because of their racial identity.

Furthermore, African American middle-class families feel obligated to establish rules and regulations as guidelines on how to negotiate the racism that exists outside the home. Willie and Reddick asserts, "Despite the successes that black middle-class families experience, the parents often feel a responsibility to prepare their children for the reality of an America that continues to discriminate against African Americans (pg. 57, 2010). Moreover, this discrimination requires parents to take the extra time, apart from work and other household duties, to further educate their children outside of what is taught in their schools. In order for parents to successfully teach and prepare their children for racism and discrimination, a certain amount of cooperation and power sharing is require between the parents. Which could explain the adoption of an egalitarian or equalitarian family 
structure, in which both the mother and father possess equal power in all family and household matters. African American families have historically adopted the egalitarian structure given the necessity of African American women having to work in order to help support their households (Jewell, 2003). Therefore, egalitarian role of men and women emphasizes a primary way in which middle class black families have adapted and changed in order to secure the success of their families.

Some working class black families also practice the egalitarian or equalitarian decision-making process in their households (Willie \& Reddick, pg. 68, 2010). These families can be quite diverse given the span of socio-economic statuses in which such characteristics exist. Due to their minority status, they are constantly having to create ways of negotiating and navigating their environment in order for them to achieve their idea of success. Thus, these particular black families have been described as "innovative marginals" (Willie \& Reddick, pg. 25-27, 2010).

Moreover, the idea that working class/low-income black families have to come up with unique strategies really magnifies the relentlessness and perseverance of people of color in the United States. "Working-class blacks are hopeful people who believe that, by hook or by crook, their innovative sacrifices will open ways to overcome or reduce adversity" (Willie \& Reddick, pg. 30, 2010). However, their innovativeness is not done in solitude; it takes the efforts of everyone in the family to ensure the successful functioning and progress of their unit. Unfortunately, this type of collective commitment keeps members of these families from participating in community activities, as well as personal time and self-care because sustaining the family is most important (Jewell, 2003). For working class families and/or low-income families, coping mechanisms involve adopting 
a non-nuclear family structure and culture. This includes the utilization of extended family, multiple generations in one household, and taking in boarders or foster children for state-funded assistance. Moreover, Jewell argues that the ultimate goal is to improve the socioeconomic status of their families, and if the government and their communities will not help them do so, then the families utilize the previously mentioned tactics in order to assure their progression. Black women have been critical to each of these varying family structures, particularly that of grandmothers.

Women in these households continue to experience many systemic barriers along race, class and gender. In particular, women from single, female-headed households have to deal with sexism in the workplace, within in their families, as well as societal judgement and stigma of being a single African American mother. However, there seems to be a large misconception about black single mothers and their survival techniques. Burgess suggests that even though they may be the only biological parent caring for their children, there is still a network of community and family members that assists with socialization of their children. "As survival mechanisms, community networks in the form of 'other mothers' and fictive kin often assist single-parent family efforts" (Burgess, pg. 33,1995$)$. Not to say that the women who headed the households are not capable of providing for their children on their own or that they do not do most of the socialization of their children, but this shows that one of the black single-mothers' most productive survival strategies is the use of community and extended family.

Moreover, the extended family structure, community networks and kinship are common patterns that exists within African American communities. Though varying family structures within the black community may experience their own set of oppression 
unique to their family, kinship is one of the best survival techniques for black families and communities. "The common cultural patterns that have contributed to the resiliency of African American families are: supportive social networks... extensive use of extended family helping arrangements; the adoption of fictive kin who become as family..." (McAdoo, pg. 22, 1998). Further, it is not uncommon for African American people to have relatives that are not biologically related to them. Of course, this is due to the community and family structures of some slave plantations, as well as the potential cultural adaptation of family structures in Africa prior to American slavery (Jimenez, pg. $546,2002)$.

As African people were captured and transported to the American colonies, many of them were separated from their families and for the sake of survival they had to create familial ties with other enslaved individuals. More specifically, the necessity to raise and protect children became one of the primary reasons to create these familial ties with strangers. Given that children were the primary concern for the fictive kin ties, older women assumed the role of mother to children and younger adults, whether they were biologically related or not (Jimenez, pg. 526, 2002).

Ironically, black grandmothers possess similar roles in the African American community today. Of course, all families are different, and their familial relationships may vary however, historically, black grandmothers have been essential to the progression and sustainability of the African American family and thus the community through the idea of kinship (Gibson, pg. 280, 2005). With this in mind, no one could deny the undoubtable role of African American grandmothers as family and community matriarchs; these women epitomize what it means to be a strong black woman as the rock 
of the family that keeps them grounded within society. Therefore, it is imperative that if we continue to study the experiences and progression of the black family in America, we have a more extensive study of African American grandmothers.

\section{Statement of Purpose}

Academic literature regarding the experience of the African American grandmother, while focusing on the resiliency of the family through the grandmother, tends to neglect the personal experience of the grandmothers. Burton (1996) did study the ways in which age norms, family role transitions and caregiving responsibilities have affected the roles of African American grandmothers in multigenerational families. However, a gap exists in the literature, in that, the social psychological experiences of these grandmothers, as crucial components of the black family structure, have yet to be fully explored. Given the many roles these women have had within the black community, it is unfortunate that there is an absence in literature regarding how they coped with such a profusion of responsibilities, not only to their own family, but extended family and the community as a whole.

Furthermore, there is a burgeoning section of literature expressing the increasing number of grandmothers becoming custodial parents to their grandchildren. Even though this is not a new phenomenon, literature suggests that in recent decades grandparents are increasingly serving as proxy parents to their grandchildren on a longstanding basis (Smith, Palmieri, Hancock \& Richardson, pg. 328, 2008). Baydar and Brooks-Gunn (1998) find that African American grandmothers had higher chances of becoming custodial parents than other racial/ethnic groups. 
In fact, the number of children in the care of their grandparents rose from 2.2 million in 1970 to 4.5 million in 2000 , and these grandmothers were more likely to be African American (Jimenez, 2002). Likewise, Ross and Aday (2006) conducted a study in which they found that African American grandmothers were 83\% more likely to be primary caregivers to their grandchildren. Thus, African American grandmothers, despite their health or financial circumstances are taking on the role of parenting rather than risking their grandchildren entering foster care (Gibson, 2005).

Even more alarming is that these grandmothers are experiencing a set of specific stressors in response to the responsibility of solely raising their grandchildren (Kelley, Whitley \& Campos, 2013; Smith et al., 2008; Smith, Cichy \& Montoro-Rodriguez, 2015). The admittance of such stress is striking given that historically, African American grandmothers have had a plethora of familial as well as community responsibilities, in addition to raising biological and nonbiological children and grandchildren (Sewell, 2013). Yet, their social psychological experiences have only recently began to be explored though the phenomenon of custodial grandparenting (Watson \& Koblinsky, 2000).

Much of the literature in black studies, as well as women and gender studies, regarding African American grandmothers and black women in general, consists of stereotypical labels, myths and other impracticable ideas of their experiences. This literature often analyzes their experiences as it pertains to their roles within the family with little consideration of who they are and what they feel as an individual (Timberlake, 1992). As Beaubeouf-Lafontant suggests, mainstream society does not, nor have they ever, viewed black women sympathetically or as feminine. Black women have been 
subjected to "controlling images" in order to perpetuate and stabilize their subordination in society, which in turn limits the worldviews and life chances of the women (2007).

One of the primary stereotypes that exist for black women, especially those with maternal roles, is that of the strong black matriarch. Which, ironically enough, is a part of the idea that the strong black woman exists as an extension or characteristic of the concept of the black matriarch (Sewell, 2013). Thus, this thesis will explore social stigmas such as the matriarch, as well as the strong black woman, in order to analyze the ways in which these images have aided in producing the strong black matriarch stereotype. Which conjure both the positive and negative impacts and outcomes for the women. Furthermore, these images will be dissected through the experiences of the interviewed grandmothers for the purpose of assessing how this stereotype has impacted their roles and responsibilities as grandmothers.

\section{Research Approach}

The current thesis is filling gaps in black studies literature as well as women and gender studies scholarship, specifically surrounding the socio-psychological experiences of black grandmother in the African American family and community. By analyzing and collecting data concerning the experience of the black grandmother, the researcher has explored how social stigmas have influenced the ways in which grandmothers have been viewed, and view themselves, within the family and community. Through a review of literature and the conduction of interviews, this thesis examined African American grandmothers' experiences and perceptions about their role as a single female head of household, and/or black matriarch in the nuclear and extended black family, as well as in the African American community as a whole. 
The sample consisted of six grandmothers, four from the southern region of the U.S., and two from the midwestern region. Snowball sampling was used, which essentially means collecting a sample through the referral from peers and social networks of the researcher. Snowball sampling was utilized because I was not sure if grandmothers were easy to access or willing to participate in this study. The willingness to participate is important because of the personal nature of the study and questions asked. The grandmothers were interviewed on a one-on-one basis through a semistructured, conversational style process. The interviews had an oral history type element and were used to construct a case study of black grandmothers.

This research assessed whether the strength portrayed by African American women, and grandmothers in particular, is a myth, defense mechanism, a true characteristic of black women, or if all are true regarding strength in black women as they experience human agency.

The specific research objectives were:

1. To examine the familial and communal characteristics of African American grandmothers, historically and contemporarily.

2. To relate the social stigmas or stereotypes of the strong black woman and the black matriarch as they pertain to the roles and responsibilities of the African American grandmother in the black family.

3. To evaluate how historical and contemporary stereotypes or controlling images of the black matriarch affect the ways in which the black grandmother is viewed and view themselves.

4. To explore the socio-psychological experiences, or emotions of the grandmothers. 
Data was collected within a three-month period. The interviews were recorded, the data was transcribed, and used along with field notes. Each interview took between thirty minutes to an hour.

\section{Structure of Thesis}

Chapter 2 is a review of the literature that explores the strong black woman, as well as the black matriarch as they pertain to African American grandmother's roles in their families. Further, this section provides a historical context to the roles that grandmothers have played in order to protect and sustain their families. Prior literature allows the researcher to position the women, their roles and responsibilities as mother and grandmothers, within a larger context of black grandmothers' historical roles.

The black feminist perspective, including womanism, intersectionality and standpoint theory are discussed in chapter 3. It begins with a general overview of feminism, how and why feminism came to be, along with the various waves of feminism. Next, womanism, as coined by Alice Walker, is discussed, followed by a comparison between womanism and black feminism. Further, black feminism is explained in depth to establish the theoretical center for this study, that includes intersectionality and standpoint theory.

A description of the methodological approach used in the study follows in chapter 4. Essentially, this section discusses the operationalization of the qualitative study in order to explore the research objectives of understanding African American grandmother's roles and responsibilities within their families. Guided by a black feminist epistemological approach, this qualitative study utilized interviews, with an oral history 
aspect so as to understand the ways in which the women negotiated their roles as black grandmothers.

Chapter 5 provides the findings from the interviews. Arranged along the themes of the research objectives. Specifically, this section provides an understanding of the historical and contemporary roles of African American grandmothers, from the perspective of the women interviewed. Then, perceptions of the strong black matriarch are discussed within the context of the ways in which the women sacrifice for their families, as well as how they cope socially and psychologically within their significant roles as grandmothers in black families.

Chapter 6 is the general conclusion of the thesis. In this section a summary of the thesis, particularly, the findings are discussed and tied to prior literature, as well as the theoretical perspective of black feminism. Further, this chapter provides some conclusions from the findings, along with a personal reflection. Lastly, areas of future research are identified. 
CHAPTER 2: THE MAMMY, THE MATRIARCH, \& THE GRANDMOTHER

\section{Introduction}

Black feminist literature tends to advocate for the unique experiences of black women. In order to do this, many contemporary black feminists emphasize the oppression that black women experience through the intersectionality of race, gender and class (Simms, 2001). In this theoretical framework, several black feminist scholars have explored the experiences of enslaved women and critiqued them through the idea of controlling images. Controlling images are the placement of certain groups in a particular status by an oppressive order that naturalizes their subordination. Further, these images influence the way other groups associate with the subjugated group, as well as how the people in the said group perceives themselves (Farrar, 1997). Patricia Hill Collins suggests that controlling images are stereotypes used to subjugate and exploit African American women throughout history (2012).

Controlling images are similar to stereotypes in that they dictate the behavior shown toward and received from certain groups, determines what is said and believed about a particular group, and can even influence how a certain group perceive themselves. Yet, they are different from stereotypes because controlling images are created specifically to disenfranchise certain groups and assure that they remain disempowered. Thus, the controlling images that were created during slavery have been 
perpetuated for the purpose of sustaining contemporary black women's subordinate positions in the family and society as a whole.

\section{The Mammy}

With the commencement of slavery, comes the exploitation of Black women in a plethora of ways. While much of the literature of black people's experience in slavery focuses mostly on the oppression, physical and mental abuse of the black male, there are some discussions and observations of the oppressions and responsibilities of black enslaved women. During slavery, African American women played an important role in the survival of their own families and the caretaking of the white family. Parallel to black women's role is the emergence of several stereotypes, including that of mammy and the jezebel (Chavan, 2015).

Simms (2001) suggests that slave owners contributed to the social construction of enslaved African women's gender roles and stereotypes. For example, personas of the mammy and jezebel legitimized the ways in which they used and exploited black women for economic sustainability. Specifically, the Jezebel is usually portrayed as the promiscuous, lustful, sex slave. According to Simms, this stereotype helped to perpetuate the idea of black women as fertile breeders during slavery. However, the icon of the mammy is in stark opposition of the jezebel.

The Mammy came into actualization during slavery and is associated with female slaves in the white household. Mammies were deemed less aggressive and thus safe and suitable to serve slave masters and their families in the home (Sewell, pg. 308, 2013). As a Mammy, Black women were household servants that mostly cared for the children of the slave master, and sometimes did other household chores. Their roles and status in the 
master's house were also seen as central and sometimes authoritative to other slaves

(Sewell, pg. 310, 2013). For example, the mammy was sagacious in the fact that she was knowledgeable of and helpful to the white family in which she provided care (Sewell,

2013). Parkhurst states that,

The 'Black Mammy' was a household servant who generally had specific duties to perform. These were mainly connected with the care of children of the family... when the children were large enough to be able to help take care of themselves, she assisted mistress in household tasks. Her sphere of influence widened with the years of her service. She was next to the mistress in authority and 'bosses' everyone and everything in the household (pg. 315, 1938).

Furthermore, Morgan (1995) evaluates the role of the mammy beyond the head house slave role and discusses the ways in which the mammy figure was visualized. She suggests that although the mammy was definitely female in the most essential ways, she has been portrayed as more masculine, with broad shoulders and a wide body frame, features which undermines her femininity.

Hill Collins (1990) asserts that the mammy was created in order to validate the economic exploitation of house slaves, and this idea was perpetuated for the purpose of explaining the longevity of Black women's confinement to menial household work. She suggests that the creation of the mammy became the basis upon which all black women are compared. Sewell (2013) writes that the mammy is the epitome of black loyalty to white authority. Sewell goes even further in stating that due to the idea that the mammy was considered a safe person, someone who does her job in taking care of the white family no matter what, she was often overlooked, which further marginalized her in the dominant society. 


\section{The Matriarch}

The black matriarch has many commonalities with the mammy. Furthermore, the matriarch is an extension of the mammy, but only within the black family. Basically, after emancipation, black women were still expected to perform the duties of the mammy, except within her own home. Sewell states, "The Matriarch takes the Black female outside of the white home and looks at her life with children and possibly a husband" (pg. 313, 2013). Furthermore, the black matriarch originated from the restriction of black men from the workforce, in which the woman is obligated to take charge in the household. Post emancipation, there was a high influx of domestic servant jobs in urban areas, creating jobs for black women. While black men competed with white men for industry jobs or farming, in which discrimination restricted them many times (Franklin \& James, 2015). Moreover, the matriarch within black communities is seen to possess characteristics such as being sassy, independent, headstrong, protective and wise (Sewell, 2013).

According to Sewell (2013), the duties of the Matriarch was not only a leader in, or of her family, but also a woman of strength, and a wife with affection toward her husband. She is to function as the head of the household, in which her energy is channeled into sustaining her children and assuring that the family functions as best as possible. Collins (1990) writes that the portrayal of black women as matriarchs permits the success or failure of the black family, and children specifically, to be placed on the black woman, instead of the social, political, and economic barriers systemically placed upom the black family. She further suggests that by not acknowledging the political and 
economic inequality affecting African American families, there is this belief that anybody can rise up out of poverty as long as they are receiving good home training.

After the Moynihan report was published in 1965, Hyman and Reed (1969) admitted that there was indeed a large, yet unspecified amount of African American homes headed by women. They went on to suggest that even in the instance that the woman was married, she still possessed predominant influence in familial matters (1969). Furthermore, in matriarch households, mothers have more influence over the children in areas such as politics, education, resiliency, cultural markers and family disagreements (Hyman \& Reed, 1969). Though the image of the black matriarch is supposed to be empowering for black women and the black family, Dobbins and Mulligan (1980) writes that black women's adoption of such ideas are merely survival mechanisms. They suggest that the idea of a matriarch should not refer to social power but a social relationship in which the black family is supported by the mother. Moreover, the matriarchy should not be considered as a myth, but as one model of familial support within structures of the black family.

\section{Strong Black woman}

The idea of the strong black woman is one that is supposed to be empowering, as it characterizes the challenges that black women have gone through and triumphed but never broken. According to Beaubeouf-Lafontant (2009), the idea of strength has been a defining characteristic of black women among the wider American society. Moreover, the concept of strength has not only been a historical characteristic of what black women have survived but it is also utilized in contemporary times to justify the expectations placed on them. Consequently, Beauboeuf-Lafontant argues that the strong black woman 
stereotype is a controlling image also used to justify their inequities and perpetuate whitemale supremacy.

Thus, the idea of the strong black woman epitomizes the concept of a controlling image because it secures the matrix of domination by making it seem as if the injustices that black women experiences are inevitable as a part of their identities as black women (Beauboeuf-Lafontant, 2009). Through the strong black woman stigma, black women have been conditioned to believe that they are supposed to accept and expect the discrimination and oppression that confronts them, all while taking care of their families with little to no support. Moreover, the concept of strength has been considered more of a performance than anything else because it focuses on what she portrays outwardly regardless of what she may be feeling or thinking.

Unfortunately, black women, especially older black women and grandmothers, have taken on this idea of having to portray the characteristics of the strong black woman during enslavement and post-slavery to ensure the safety and production of their families. Besides taking on the image themselves, close to impossible tasks are assigned to them and are justified because they can handle them, according to the image of the strong black woman (Beauboeuf-Lafontant, 2007). Of course, the justification of this controlling image or stereotype will continue to exist as long as it is not addressed through the actual experiences of black women and how they perceive and negotiate such an image, as was the case in the past. 


\section{History of African American grandmothers}

In Africa, prior to the Atlantic Slave Trade, there were traces of matriarchal, matrilineal, and other forms of female-headed community structures in some cultures and societies (Farrar,1997). Staples (1981) defines these types of family structures as existing in a society in which basically all the governing power over family, inheritance, and the home are administered by the elder women of the community. Thus, it would not be surprising to identify traces of African gender culture in the matriarchy throughout the different eras of the African American community, especially given the emasculation of the Black man in the American society (Franklin \& James, 2015). Further, it has been the older Black women, usually grandmothers, that have taken on the roles of family and community mothers, or matriarchs, to raise children and keep the home African American intact. Sewell (2013) describes these figures as heads of their homes whose primary interest and concern is the maintenance of her strength for the sake of her family's preservation. It has been the Black grandmother's maintenance of strength, or the portrayal of strength on the surface, that has been crucial to the conservation of the Black family in America.

Regarding African American women's role in Black people's struggle against racism, Staples (pg. 27, 1981) contends that one will usually encounter the assertion that the Black community is organized as a matriarchy. Staples goes on to suggest that had African American women taken on the passive role attributed to the female gender, the Black race in America could have very well gone extinct within the past four centuries (pg. 28, 1981). Thus, if Black women, African American grandmothers specifically, had not taken on the role of a matriarch and believed in the idea of the Strong Black Woman, 
the progression of the Black family and community would not have been possible. For centuries, starting with the Mammy during slavery, Black grandmothers have bared the issues of the Black family for the sake of their safety. Furthermore, it is important to note that throughout the literature, terms such as mamma, mama, Big Momma, aunt, great aunt, great grandmother, older Black women, and grandmother are seemingly synonymous (Gibson,2005; Jimenez, 2002; Sewell, 2013).

Historically, with the role as mammies, grandmothers have not only taken care of white children, but were essential in the lives of slave children, as mothers and fathers had to work and were sometimes permanently separated from their children. Specifically, these grandmothers or Mammies possessed a number of duties within the slave quarters such as midwives and wet nurses, cared for and schooled the children, as well as provided medical and healing services for slave families and white families (Jimenez, pg. 526, 2002). According to Davis (1971), "Even as she was suffering under her own unique oppression as female, she was thrust by the force of circumstances into the center of the slave community. She was, therefore, essential to the survival of the community" (pg. 11).

Furthermore, grandmothers' collective responsibility of children during slavery reinforced ideas of fictive kin because these women presumed the role of grandmother or mother to all children within their care whether they were biologically related or not.

Further, given that grandmothers were almost always the midwives, they were considered grandmothers to all the children they delivered (Jimenez, p. 527, 2002).

Moreover, toward the end of slavery, grandmothers often assumed responsibility for their grandchildren as more Black people were being emancipated. Though 
emancipation seemed promising, it is also something that further separated the family as parents migrated for work, leaving many grandmothers with no choice but to step in with partial or full care of grandchildren (Franklin \& James, 2015).

Grandmothers fiercely resisted the practice of local authorities binding our orphaned African American children to their former white owners; they would travel across state lines to rescue their grandchildren from such situations, which they felt were akin to reenslaving them, much to the puzzlement of white authorities (Jimenez, pg. 527, 2002).

Practices as mentioned above, as well as providing a counternarrative to slavery and racism followed grandmothers through to the time of Reconstruction ${ }^{1}$. Jimenez (pg. 530, 2002) asserts that grandmothers offered distinct features to the African American community during Reconstruction such as healers, producing raw materials for sale in order to generate income for the family and community, and even providing an empowering interpretation of their, or their ancestors, time in slavery to young Black children. Additionally, they regulated the homes while the younger adults worked in manufacturing jobs and did field work. Thus, grandmothers assumed many roles for the sake of the cultural and economic progression of the Black community, none of which necessarily benefited them individually. Yet, they took pride in these roles and performed them outstandingly.

Given the flexible, important roles grandmothers played as well as the fact that they often outlived their children and husbands, many of them possessed high statuses in

\footnotetext{
${ }^{1}$ Reconstruction is the era of American history following slavery, spanning from 1965-1977. This era ushered in a myriad of compelling changes in the African American family. Specifically, Reconstruction altered the social, legal, and economic experiences of the African American family, as many of the husband and fathers worked, and single mothers often had to leave their families for significant amounts of time in order to find work. (Franklin \& James, 2015).
} 
communities across the Depression-era South ${ }^{2}$. Their survival of slavery, racism and poverty further reinforced their status in their communities. Moreover, during this time, it has been noted that some older Black women that did not have any biological children or grandchildren, often accumulated many fictive or adopted children and grandchildren (Jimenez, pg. 531, 2002). Further, grandmothers offered surrounding neighbors, including white families, assistance with their children when they went to work. Black grandmothers willfully took responsibility for all children, regardless of her own living situation. It is not known whether when a grandmother headed a home, if she was the primary authority to the children, even if their mother was present in the home as well (Jimenez, pg. 531, 2002).

Just as during Reconstruction, during the Depression of the 1930's, Black grandmothers were the primary source of family cultural traditions and history. The stories they relayed to their children and grandchildren provided information about cultural roots as well as the ideas of hard work. They not only provided insight into the past but gave their grandchildren hope and aspirations for the future. "Grandmothers encouraged their grandchildren to leave the rural areas of the South to find work or obtain an education" (Jimenez, pg. 533, 2002). Black grandmothers were also natural herb doctors during the Depression-era South, skills that had been passed down to them from their grandmothers (Jimenez, 2002). These examples of roles and knowledge base speaks

\footnotetext{
${ }^{2}$ The Great Depression is an era of American history that span between the years of 1929 and 1939. Similar to Reconstruction, The Great Depression further altered the familial experiences of African Americans. Specifically, in the American South, many black men had migrated north, leaving many black women with the rearing of children. Thus, these women either had to leave the home and find work, or attempt to gain some kind of public assistance or social insurance through a federal program (Franklin \& James, 2015).
} 
volumes to the emphasis put on the influence of grandmothers and passing on traits to future generations.

Following the era of the Great Depression, and into the latter years of the Great Migration $^{3}$, African American women were being offered more domestic jobs in northern cities, which only perpetuated the idea of grandmothers as caretakers of children in the South and kinship ties. Jimenez noted, "While many grandmothers reared their grandchildren in the South, the parents of these children went north looking for work after the near collapse of southern agriculture" (pg. 535). Moreover, as more and more African American married women moved north to work to help support their families, grandmothers were also having to migrate to the north or make frequent trips from the South, in order to help with children, cooking, laundry and other household tasks that were essential to the family. Sadly, some grandmothers migrated north to raise grandchildren in the instance of death the of a parent. While they recognized that it was different and sometimes difficult to raise children in the north, they took pride in being able to step in and care for their grandchildren (Jimenez, 2002).

In the mid to later years of the twentieth century, some African American families had become middle-class or affluent families. Thus, the role of grandmothers, though still very important, was different for these families. According to Jimenez (2002), "Many of these older women joined women's clubs, which proliferated among middle-class African American communities..." Further, these women's clubs proved to be critical social and political outlets for Black women as well as the African American community

\footnotetext{
${ }^{3}$ The Great Migration spanned nearly 50 years, as a time in American history when many rural, southern African Americans migrated, North, Mid-West, and West to urban industry cities for what they believed were better economic opportunities (Franklin \& James, 2015).
} 
as a whole (pg. 538). Affluent and middle-class grandmothers still played a crucial role in the lives of their grandchildren, given that these grandmothers continued to be the primary source of family ethnic history. Additionally, these grandmothers provided important disciplinary action for the grandchildren, as these children were observed to be extremely mannerly and obedient (pg. 538). This implies the high respectability that existed for elders and especially African American grandmothers in these communities.

Lastly, Jimenez explains that these kinds of grandmother-to-grandchild relationships, in which the grandmother was not necessarily in the home but still pivotal, help to solidify the sentimental attachments to grandmothers as emotional anchors of the affluent African American families. Although the grandmother was not a primary caregiver or financial supporter, she was still considered a treasure to be cherished (pg. 539).

Though some African American families were able to advance in society class wise, there were still high volumes that remain in low-income and impoverished communities. So, grandmothers' roles in these families proved to be similar to what they had been in families that lived in the Plantation ${ }^{4}$ and Reconstruction south, especially post World War II through the 1970's. Considering that many mothers were working as in-home domestic workers, grandmothers cared for the children while their mother was away from the home. It was under these kinds of circumstances that the sacred motherdaughter relationship was strengthen for the sake of childrearing (pg. 542), and the idea of kinship ties reinforced.

\footnotetext{
${ }^{4}$ The Plantation South is synonymous to the term Antebellum South. This era of American History is preCivil War and describes a time in which the American South economically thrived from slavery, or plantation labor. Thus, within in these plantations, black people possessed unique familial and community structures, that emphasized kinship (Franklin \& James, 2015).
} 
The grandmother was the central figure, and essentially the matriarch. In economic turbulent times, family members always went to "Momma" or the grandmother because even though she may not have had a legitimate source of income, she always had resources. Family members would often provide financially for grandmothers. Even in situations when the grandmother did not live in the same house, many families stayed within close proximity of one another for economic and childrearing support. "... These localized family groups are the focus of childrearing; they are an economic boon to working parents and are the agents of socialization" (Jimenez, pg. 543, 2002).

\section{Kinship and Kinscripts}

Because of economic and social factors, African American grandmothers often served as custodial parents or intergenerational parents. Smith, Cichy and Montoro (2015) make the assertion that these types of family household structures are known as custodial or skipped generation families. Baydar and Brooks-Gunn (1998) further states, “In the late 1980's, immediately following a decade of rapid social change in the ways families were organize just under one half of all grandmothers in the U.S. were providing care for at least one of their grandchildren" (pg. 386). Thus, African American grandmothers, despite their health or financial circumstances are taking on the role of parenting rather than risking their grandchildren entering foster care (Gibson, 2005).

Fortunately, and unfortunately, this is the role that grandmothers have been assigned according to their kin-work within their families. Kin-work is one third of the concepts that make up the framework of kinscripts. Stack and Burton describe kin-work as the as the tasks a family must complete in order for them to survive and progress from generation to generation (1993). 
There have been a number of factors that have led to Black grandmothers becoming primary caregivers. Watson and Koblinsky (2000) found that factors leading to grandmothers' increased role as custodial parents include longer lifespans, divorce and single-parent headed families, as well as teenage parenthood. Additionally, Ross and Aday (2006) found that common reasons for African American grandmothers becoming custodial grandparents was due to the parents being in school, working or having an unreliable job (pg. 918). Kelly, Whitely and Campos (2013) states that, "In addition to the caregiving role, the reasons that grandmothers were raising grandchildren (e.g., parent's incarceration, substance abuse) undoubtedly added to their stress" (pg. 375).

Gibson (2005) explains that today, with their new role of parenting, grandmothers must now provide basic needs for their grandchildren, while preventing them from getting involved with gangs, drug use, premarital sex, help them stay out of trouble in school and keep them from having negative interactions with law enforcement. Gibson also asserts that Black grandmothers are under a lot pressure to properly socialize their grandchildren in a way that would overshadow the mistakes made by the biological parents. Moreover, many children tend to act up because of the psychological trauma of dealing with an absent parent (pg. 291-292). Timberlake and Chipungu (1992) propose that given African American grandmothers' concern for the honor and maintenance of their families, that have often willingly committed themselves to be in self-sacrificial positions for the sake of their younger generations (pg. 218). Therefore, it would be apparent that intergenerational parenting yields quite a few psychological and emotional problems for many of the grandmothers within the twenty-first century. 
Kelley and Whitley conducted a study assessing psychological distress levels of African American grandmothers that are custodial parents and found that $40 \%$ of the grandmothers fell into a clinical range on a psychological distress scale (pg. 375, 2013). Watson and Koblinsky's study found that grandmothers and great-grandmothers reported chronic stress with their role of becoming primary caregivers (2000). Additionally, Smith, Palmieri, Hancock and Richardson (2008) conducted a study and found that the new stressors of becoming custodial parents adds psychological distress to a population already possessing certain vulnerabilities. They also concluded that parenting stress for custodial grandmothers correlated with their reported elevated levels of depression.

Further, Smith, Cichy, and Montoro-Rodriguez (2015) found that due to financial strain, lack of formal and informal support, lifestyle disruption, conflict with biological parents and health changes, intergenerational grandmothers were experiencing increased levels of psychological distress. One would have to inquire whether these elevated levels of psychological distress have always existed for African American grandmothers, given that, historically, many of them have always had critical roles in raising their grandchildren. 


\section{CHAPTER 3: THEORETICAL FRAMEWORK- BLACK FEMINIST THOUGHT}

African American grandmothers are a very unique group of individuals to study. Therefore, in analyzing their experiences it is essential to utilize a theoretical lens that is capable of encompassing their lives and experiences. Thus, for the purpose of this study, black feminist thought was utilized as the theoretical framework to analyze the experiences of African American grandmothers interviewed. Black feminist thought is discussed along with womanist theory, while specific focus is given to experiences of oppressions involving the intersections of gender, race, and class. Intersectionality is used to expand the black feminist perspective. Further, standpoint theory was also explored as African American grandmothers potentially possess their own understandings and perspectives of their experiences.

Black feminist perspective and theories such as standpoint and intersectionality are crucial in analyzing the of roles and experiences of women of color. Moreover, these theories help to provide a social and historical context in which to study black women as a distinct group from black men and white women. The chapter will begin with a description and critique of Feminism. From there, the researcher will transition to Black Feminism in order to densely incorporate race into the feminist perspective. Womanist theory and black feminism will then be compared. Next, the concepts of standpoint, specifically black women's standpoint will be examined. Then intersectionality is 
explored before tying it all together and exploring the core tenets of black feminist perspective.

\section{Feminism}

A simple definition of feminism would include the belief that women are more than capable of participating, as well as leading within any context, including socially, intellectually, sexually, politically, economically, and spiritually (Cleage, 1993). Throughout history, feminism has included a myriad of ideas, as well as social and political movements, in order to advocate for equal rights for women. Feminism has primarily focused on sexual equality and challenging sexist oppression within patriarchal societies and cultures (Shamase, 2017). Feminism as a western concept, as ideologies, and as political and social movements have manifested and triumphed for the sake of women's rights globally. Furthermore, the concept of feminism is ever growing and developing; hence, waves of feminism evolved over time.

Gordon (2013) explains that although ideas of feminism have surfaced as far back as the 1800's with the women's suffragists movement, which is considered the first wave of feminism, the most popular era, especially in scholarship, would be the second wave. Second wave feminism flourished between the 1960's and 1980's out of social movements concerning equal rights in the areas of class, gender, sexuality, education, and race among others. Gordon suggests that second wave feminism was probably the largest social movement at its peak. However, given the fact that this era of feminism shared many of the same strategies of the Civil Rights movement, gay and lesbian liberation movements, the anti-war movement, along with the intertwining of participants within each movement, that would be a tough argument to make. 
Furthermore, second wave feminism, was mostly centered on white, middle-class women, even though women of color were major contributors and leaders of activism, as well as feminist scholarship (Shamase, 2017). The diversity within this era of feminism was critical in the magnitude and successes of the movement. In fact, the ideas that form mainstream, white feminist theory have historically been co-opted from black feminists' perspectives and activism. Black feminist, such as Ida B. Wells and Maria Miller Stewart had been arguing on behalf of the intersection of race and gender since the women's suffragist movement of the 1800's (Henderson, 2013; Ochiai, 1992).

Therefore, it is not surprising that feminism at this time was to be considered a form of liberation for all women as it addressed the commonality of sexism, political and cultural oppression they all experienced. According to Shamase (2017), this era of feminism was never meant to benefit any class or race of women, as it was merely meant to challenge the cultural and social roles of men and women in society. Further, Roth suggested that this era of feminism was different from the other waves of feminism because it was organized by women of many racial and ethnic origins (2004). For example, feminist scholars of color, like bell hooks, suggest that their activism was birthed out of the arguments against classism and racism within white feminist ideology (hooks, 2000).

Despite the many waves of feminism, there are core tenets that constitute fundamental issues argued for in feminist context. Foremost, second-wave feminists were concerned with economic equality, especially in regard to the international poverty of women. They advocated for equal rights of educational opportunities, employment policies and inheritance laws (Collins, 1996). Political rights were core to feminist studies 
and activism. Within this tenet, feminists advocated for voting rights, the right to assemble, rights for prisoners, and basic human rights (Collins, 1996). Additionally, there was advocacy against sexual violence, such as harassment, rape and torture of women. Along with the previous tenet, family and marital issues that encompasses the advocacy for favorable divorce laws, child custody policies and domestic housework. Lastly, second-wave feminist campaigned for women's health, that included reproductive rights, sexuality, sexually transmitted diseases and infections, and of course pregnancy (Shamase, 2017).

Though all the above-mentioned tenets of feminism are a part of black feminist perspectives, feminism has often been perceived as the property of white women (Caraway, 1991). Hence the lack of acknowledgement for black women's self-definition and self-evaluation, the intertwining of their different oppression, or the necessity of a unified, conscious fellowship of African American women in traditional feminism (Collins, 1986). Traditional feminist perspectives, dominated by white women, fails to acknowledge the subtle and, or major differences in diverse needs between different populations of women. This includes women of color, impoverished women, women of immigrant status, as well as those that fall within the categories of LGBTQI (Rousseau, 2013).

\section{Black Feminism}

Black feminist had to reassert themselves as a response to the humiliation of feminism. Smith (1998) suggests that black feminism is motivated by the desires of black women to disrupt categorical oppressions, while strengthening the legacy of African American women's intellectual history. In other words, black feminism should be 
considered a theoretical interpretation of black women's reality, by black women.

Furthermore, black feminism asserts advocacy for the interconnectedness of oppression in the day to day lives of not only black women but other marginalized women (Rousseau, 2013). Moreover, the use of black feminism is relevant because it places African American women in a position to analyze their oppression in America, as it relates to women's oppression internationally (Davis, 1981).

Black feminism emerged as a critique of feminism for focusing the fight on middle-class white women, with little regard to the plight of women of color and women of lower socioeconomic status (Johnson-Bailey, 2003). Walkington (2017) suggests that black feminist thought provides a lens for African American women to understand their experiences, especially their experiences of oppression. She further suggests that black feminism is to be utilized by black women to eradicate the discrimination they encounter within the feminist movement. Hence, black feminism challenges the racist ideology that feminism is only for white women (Collins, 1990). Simply, a definition of black feminism would be a movement and ideology that addresses the issues of racism and sexism that oppresses women of color in the United States (Johnson-Bailey, 2003). Though the previous definition may only seem applicable to African American women, black feminism is all inclusive because it not only seeks to address racist and sexist oppression, but all form oppression. It is offered as a point at which all opposition to the status quo can be met and resisted (Johnson-Bailey, 2003).

Though black feminism can be considered all inclusive, it is indubitably a theory and movement created by black women, for black women. "As black women we see black feminism as the logical political movement to combat the manifold and 
simultaneous oppressions that all women of color face" (The Combahee River Collective, pg. 276, 2014). Prior to the coining of the term feminism, there had always been black women activists advocating for their sexual identity and freedom, as well as their racial identity and freedom. There were black women fighting and advocating during the women suffragist movement as well as the abolitionist movement thus, it is only right that contemporary black feminist build upon their political, social and cultural struggles to create a discourse for their own struggles. Moreover, it is crucial for black women to acknowledge the commonality of their experiences in order to form a unified consciousness for the sake of ending their specific set of oppressions. Besides the recognition of common experiences, black women must realize their worth and necessity for their own fight for liberation. Considering,

... no other ostensibly progressive movement has ever considered our specific oppression a priority or worked seriously for the ending of that oppression. The mere names of the pejorative stereotypes attributed to black women (e.g., mammy, matriarch, Sapphire, whore, bulldagger), let alone cataloguing the cruel, often murderous, treatment we receive, indicates how little value has been placed upon our lives during four centuries of bondage in the Western hemisphere. We realize that the only people who care enough about us to work consistently for our liberation is us. Our politics evolve from a healthy love for ourselves, our sisters, and our community, which allows us to continue our struggle and work (The Combahee River Collective, pg. 272, 2014).

Therefore, contemporary black feminism is an acknowledgement, challenge, result, as well as a maturity from the plethora of sacrifices made by the mothers, sisters, scholars and activist of generations before them.

Nonetheless, some scholars have made some critiques of black feminism. For instance, Collins (1996) suggests that resistance to the pressure of absorbing racist feminist ideas keeps black feminists from focusing on the real issues and concerns of the 
African American community. Collins further argues that while some black feminists are too busy trying to critique traditional feminism, they are not actually making any real progression against the other societal oppressions for black people. Another critique of black feminism would be its lack of inclusivity for black lesbians. Collins (1996) makes the assertion that as a collective, black women have a tendency to distance or remove themselves from movements that are associated with the acceptance of homosexuality. She also suggests that black feminism has been portrayed to be exclusively for black women, intentionally rejecting African American men. Some see this as critique to black feminism, and adopt instead the idea of womanism.

\section{Womanism}

Womanist theory, also known as black womanist theory, or Africana womanist theory, is actually very similar to black feminist perspective. The two theories were actually birthed out of the same era of political and social activism, and academic discourse. Both theories explore the intersectional perspectives that are essential in analyzing the multiple oppressions experienced by black women. Simply put, womanist theory asserts that black women have historically existed within an intersection of gender and racial oppression (Harvey, Johnson \&Heath, 2013; Rousseau, 2013), which, in theory is no different from black feminism. Similar to black feminism, womanism as a discourse is a critique of feminism for its historical lack of inclusivity for all women. Rousseau (2013) suggests that one of the major, defining facets of womanism is concerned with historical struggle for black women's rights to be connected with black men, which is something often not emphasized in black feminist perspective. Further, this is in stark 
contrast to white, middle-class feminism, as it was not designed to create and sustain relationships between men and women.

The term Womanism was coined by Alice Walker, who described it as a feminist of color perspective that is committed to the preservation and wholesomeness of all African Americans (Rousseau, 2013; Walker, 1983). Additionally, Walker (1983) believed that the experiences of African American women were significantly different from the experiences of white women. Thus, no form of feminism was sufficient to analyze the experience of African American women, as feminism is inherently a white women's discourse. Rather, womanist theory places the agenda of Black experiences at the center, rather than a marginalized population on the fringes of white feminist perspectives (Rousseau, 2013). Womanism is specifically rooted in African American women's tangible historical experiences of racial and gendered discrimination (Rousseau, 2013). Further, Walker (1983) suggests that the concrete experiences of black women nurtures a womanist worldview that should be exclusive to black women.

Womanism offers a way for black women to argue and advocate against gender oppression, without ridiculing black men, which is essential to many African American women (Harvey et al.,2013). Basically, womanism is adamant about not creating any other issues in the black community, but rather provides a framework to address the issues that already exist within the black community. Due to womanism's commitment to the wholesomeness of all African Americans, womanism addresses the colorism that exists within African American communities, which is an advocacy for all people of color (Hubbard, 2010). LaRese Hubbard (2010) further suggests that womanism is an authentic paradigm that is grounded in both family relations and race relations. 
Furthermore, Hubbard (2010) asserts that womanism is grounded in black culture and is thus inevitably focused on the experiences, desires and oppressions of black women.

Considering that womanism is grounded within many theoretical perspectives, it is an emphasis of how interconnected black women are within society (Harvey et al., 2013). Thus, womanism promotes a participatory approach by emphasizing the necessity of black women telling their own stories as it connects to the varying areas in society, as well as the varying discourse of academia. This in turn aids in the validation of black women's individual experiences (Harvey et al., 2013). Womanism believes in the value of older and aging black women, as they are considered "possessors of knowledge and recognizes their experiences as valid sources of information" (Shambley-Ebron and Boyle 2006). This understanding epitomizes the essence of Walker's In Search of Our Mother's Garden (1983), as she utilizes the experiences and stories of the black women, black women artists and scholars before her to help create a framework to analyze her experiences and art.

Fundamentally, womanism and black feminism are not that dissimilar; womanism places more emphasis on the sustainability of the African American community as a whole, instead of just fixing the issues of black women for the sake of saving the black community. However, many use the two terms synonymously. Omolade (pg. 173, 1994) states, “... black feminism is sometimes referred to as womanism because both are concerned with struggles against sexism and racism by black women who are themselves part of the black community's efforts to achieve equity and liberty." Even Walker recognized how interchangeable the two terms or theories are, given that they are both theories for black women, by black women, while still acknowledging the 
intersectionality of race, class, gender and sexuality in black women's oppression (Harvey et al., 2013). In order to demonstrate the slight differences between womanism and black feminism, Walker states, "womanist is to feminist as purple to lavender" (pg. 64 1983).

\section{Intersectionality}

As a theory, intersectionality was introduced in the 1980 's as a pragmatic term that explores the solidarities of sameness, along with the variations in anti-oppressive, social movements (Cho, Crenshaw \& McCall, 2013). Intersectionality was created to identify the ways in which monolithic thinking demoralizes the political thinking, academic scholarship, and struggles for and against social and cultural oppressions (Cho et al., 2013). "Intersectionality's insistence on examining the dynamics of difference and sameness has played a major role in facilitating consideration of gender, race, and other axes of power in a wide range of political discussions and academic disciplines..." (Cho et al., pg. 791, 2013).

Intersectionality is credited to Kimberle Crenshaw in her 1991 work, Mapping the Margins: Intersectionality, Identity Politics, and Violence Against Women of Color. She suggests that intersectionality is a theoretical acknowledgement towards a theoretical understanding of how critical it is to consider the intersections of multiple oppressions (Crenshaw, 1991). Surely, she did not create the ideas behind intersectionality, but rather just placed a name on it (Walby, Armstrong, \& Strid (2012). However, Crenshaw's work has been central to the discussions of intersectionality in black feminist perspective. Walby et al., (2012) even suggests that Crenshaw utilizes the idea behind intersectionality to address the ways in which the multiple oppressions, race and gender, of black women 
limited their access to the American labor market in her 1989 article, Demarginalizing the Intersection of Race and Sex.

Nevertheless, Crenshaw's basic premise for coining intersectionality theory resided in the fact that black women's experiences and encounters with oppression were not adequately addressed in the traditional discourses of racial and gender discrimination as they were understood at the time (Crenshaw, 1991). Further, she felt that black women, being placed at the intersection of race and gender, were easily marginalized. Thus, they encountered restricted options within the social and political discourses that addressed oppressions of race or gender, instead of having substantial representation in a discourse that addressed both race and gender (Crenshaw, 1991; Walby et al., 2012).

Moreover, in academia, especially within black feminist discourse, intersectionality has helped with analyzing social, cultural and political inequalities. Intersectionality has not only aided in black feminism's understanding of social inequality, but also with challenging the social inequalities and the lack of power for black women (Collins, 2012). Black feminists had been advocating against the injustices that plagued black women through race, class, gender and sexuality with no tangible theoretical perspective or name. Furthermore, black women had been the leaders of movements that addressed such injustices in their everyday lives, and thus their scholarly provided a foundation for the ideas of intersectionality, yet intersectionality has provided a theoretical discourse for black feminist to address their lived injustices.

\section{Standpoint Theory}

Given black women's intersectionality of race, class, gender and sexuality, their understanding of their experiences may vary, or may not be relatable to those who do not 
share their same oppression, due to their social location. Standpoint theory has been understood as the epistemological basis of feminism (Harding, 2009). Moreover, standpoint theory has been characterized by the idea that knowledge is systematically framed, so those that are marginalized or oppressed through systemic injustices possess an advantageous perception of society in contrast to those that are not marginalized (Wylie, 2012). In other words, individuals that are privileged do not recognize the injustices and oppressions that exist in the world.

Intersectionality is a key component to understanding the necessity of standpoint theory within back feminism. Given that the multiple oppressions that black women face all equally contribute to the injustices against them, these cannot be evaluated separately for black women (Harnois, 2012). Further, the intersection of race, class, gender and sexual experiences of black women positions them at a unique vantage point in society. Collins (pg. 448, 2012) states that, “... the particular experiences that accrue to living as a Black woman in the United States can stimulate a distinctive consciousness concerning our own experiences and society overall.” Thus, black women's standpoint is categorized by their encounter with the intersectionality of oppression that are formed from racist, classist, and gendered inequality, along with the historical basis of legacy of struggle against the said oppression (Harnois, 2009).

Specific to a black feminist perspective, standpoint theory allows for the reflection of power relations as a challenge to gaining and creating knowledge. Further, standpoint theory promotes a framework for producing knowledge within a social context. In other words, the use of standpoint theory within black feminism allows black 
feminist and black women to advise social scientist in creating scientific knowledge about their experiences, while generating evidence to empower themselves (Rolin, 2009).

\section{Core Principles Within the Black Feminist Perspective}

There are five specific principles that permeate through any and every form of black feminist perspective, including, but not limited to, research, art, and activism. These principles are visibility, recognition of unique status, empowerment, intersectionality, and resistance (Collective, 2014; Collins, 1991; Hooks, 2000; Lorde, 1995; Richardson, 1987; Smith, 1995). First, there is the principle of visibility within black feminist perspective. Given the concern of black women's invisibility within academia, social movements, and other areas of society, visibility is one of the primary principles that black feminist advocate for. Due to black women's marginalized positions within black liberation discourse and feminist discourse, many of their contributions are forgotten or ignored. Thus, in many instances they are overworked and undervalued considering their lack of positions of power (Beoku-Betts \& Njambi, 2004). Furthermore, black feminist's deliberate focus on black women exemplifies the roles and responsibilites that black women have possessed and makes them more visible within a social context.

Next, there is the tenet of recognizing the unique status of black women. By recognizing the unique status of African American women, black feminists are revealing the fact that intersectionality of race, class, gender and sexuality creates a inimitable identity and reality that deserves its own discourse (Collins, 1991; Smith, 1995). Due to the fact that black women's interest and contributions were being ignored, along with the lack of adequate representation in black studies or feminist studies, black feminist 
decided that the recognition of their unique status as black women was essential for the sustainability of black feminist thought. Along with this principle, is the recognition that there is variation within the lives of black women. Furthermore, this principle promotes research on both black people and women (Smith, 1995).

There is also the principle of empowerment within the black feminist perspective. The black feminist perspective allows for black women to tell their own stories, allowing them to define themselves, and also provides them a lens to interpret their experiences and definitions for themselves, which in turn empowers them (Harvey, 2013). Moreover, the black feminist perspective provides a theoretical framework to analyze the experiences of black women, which in turn allows for the possible positive feedback and affirmations of other black women (Harvey, 2013; Smith, 1995). Again, this empowers black women but in this case it is within a collective context instead just empowering the individual.

Another core principle within the black feminst perspective is intersectionality. As mentioned in the previous sections, intersectionality is critical in analyzing and understanding the experiences and oppressions of black women. Barriteau suggests that intersectionality is a key component in which black feminist have organized around (2008). Considering that race, class, gender and sexuality all equally contribute to the experiences and oppression of black women, it is essential that these facets be analyzed as they affect and build off of one another (Walby et al., 2012). Furthermore, any discourse that does not analyze black women's experiences through intersectionality only perpetuates their oppression in society (Barriteau, 2008). 
The last core principle of the black feminst perspective is black women's resistance. Certainly, black feminsim in itself is black women's resitance, considering it is formed out of the necessity to no longer be ignored within black studies and feminist studies. Furthermore, the black feminist perspective provides ways in which black woman can resist against other forms of oppression, while avoiding being labeled as victims (Collins, 1991, 2009; Hooks, 2000; Richardson, 1987). Black feminist made it a

part of their mission to ensure that black women try and interrupt the standardized idea of black woman as objects by providing scholarship that portrays black women and their experiences as valuable (Beoku-Betts \& Njambi, 2004). Moreover, black women's varying modes of resistance should be utilized to better understand the various oppressions that plague their realities (Barriteau, 2008).

\section{Black Feminist Perspective as a Tool of Analysis}

The black feminist perspective should be utilized as the primary tool in analyzing and synthesizing around the experiences of African American women. When the experiences of African American women are explored within their historical context, the understanding that the black feminist thought was born from the activism of black women is quite simple to grasp (Rousseau, 2013). Thus, when exploring the experiences of the African American grandmothers, the black feminist perspective provides historical as well as contemporary context for analysis.

Moreover, the participatory approach is essential when implementing the black feminist perspective. This allows for black women, and in the case of this researcher, black grandmothers, to provide insight about their experiences, which helps to strengthen the discourse of black feminism by capturing the varying experiences of everyday black 
women (Harvey et al., 2013). Barbara Smith suggests that by capturing the varying experiences of everyday women, the black feminist perspective has granted black women the understanding that their experiences are not devlauled, nor abused at fault to themselves, but rather they are apart of a system created by patriarchal, white men that set the standards of society (1995). For the sake of this thesis, capturing the everyday experienes of the African American grandmother will exemplify the ways in which social structures and ideologies have impacted their lives, and thus their families and communities. 


\section{CHAPTER 4: METHODOLOGY}

This thesis examines the experiences, roles and responsibilities of African American grandmothers utilizing a qualitative research approach. Further, this kind of approach acknowledges that the perspectives of the participants exist within an intersection of their social realities and living conditions (Dandekar, 2005). The advantage of utilizing a qualitative approach allows for a meaningful and culturally salient examination of the women's experiences (Creswell, 2009). Further, a qualitative approach opens up the study to reveal and acknowledge experiences and perspectives that

could be potentially unanticipated by the researcher (Silverman, 1997). Specifically, the research adopts an in-depth, yet semi-structured interview, utilizing an oral history traditional approach to explore the grandmothers' experiences.

Moreover, this chapter describes the research approach as well as the logistics behind how the data for this thesis was collected. It starts with a restatement of the purpose of the study, as well as a restatement of the primary research questions. Furthermore, this chapter introduces the participants that were interviewed, the sampling procedure, the analyses process, and the interview questions.

\section{Purpose}

This thesis explores the roles and responsibilities of African American grandmothers as they pertain to the sustainability of the black family. Specifically, it attempts to analyze the persona of the black matriarch in order to assess whether the 
characteristic of strength is one that black women, specifically grandmothers, just possess; whether the characteristic of strength is a myth or real. Further, the thesis seeks to explore whether the injustices that black women experience are inevitable as a part of their identities as black women. Essentially, do black women accept and expect the discrimination and oppression that confronts them as an inevitable aspect of their identities?

\section{Sampling}

To find the participants necessary for this study, snowball sampling, or as some would call it, referral sampling, was utilized. Essentially snowball sampling is the use of the researcher's social networks to aid in seeking out possible subjects or participants for the study. As Noy (2008) states, snowball sampling is when the researcher, “... accesses informants through contact information that is provided by other informants... informants refer the researcher to other informants, who are contacted by the researcher and the refer him or her yet other informants, and so on" (pg. 336). This is a technique often used to

find and/or recruit a hidden, or vulnerable population; in other words, a population that is not easily accessible or willing to participate through other sampling techniques (Waters, 2015).

Moreover, this specific technique is utilized for the sake of this study because, though African American grandmothers are abundant, they may not always feel comfortable with disclosing information to a stranger. Due to things such as the eugenics movement, the Tuskegee experiment, and other scientific studies that have either 
physically harmed or further oppressed people of color, African American black people possess a mistrust of scientific research. Thus, the use of social networks creates a line of trusted communication beforehand so that the participants are comfortable enough to communicate with the researcher. For example, using my peers as an introduction to grandmothers also establishes trust. Also, those who knew my own grandmother were more trusting and more willing to share their life stories with me. Furthermore, grandmothers have their own social groups and could recommend other grandmothers that they feel would be interested, or even impactful, to study's objective.

\section{Participants}

This study analyzes, through interviews, the life and experiences of six grandmothers. Four of the grandmothers are located in the southern region of the United States, while the last two are located in the southern part of the mid-western region of the United States. The researcher asked peers and colleagues if their grandmothers would be willing and able to participate in the study. Once contact was made with certain grandmothers and the study was described, the participants decided if they wanted to consent to the study; some even directed the researcher to other grandmothers they felt would more suitable for the study than themselves.

Due to the sensitivity of some of the information provide within the study, pseudonyms were provided for each grandmother. Basically, by providing a pseudonym to the participants, their identities are protected and none of the information they provided can be traced back to them. In selecting pseudonyms for the participants, the researcher decided after the interview and went with a name that was related to a certain part of the interview. Some of the names may be simple, in that they are just other ways 
of saying grandmothers; others may just relate to a certain aspect of their personality or experiences as observed by the researcher.

\section{Participant 1}

The first grandmother to be interviewed, given the pseudonym "Dottie", she was a soft-spoken 77-year-old gem. She was a fair-skinned, slender, and kind of tall. She had dark, curly, shoulder-length hair. She was a little soft-spoken in the interviews, maybe even a little timid, but that was something she admitted to during the interview. However, she did seem to possess this middle-class attitude, that could come off a little arrogant.

She had a rural, midwestern upbringing. She grew up in a very small town, where she was number six of nine siblings. Thus, she came from a rather large family, especially when extended family is included. Ultimately, her family comprised of most of the people of color in their small town. Given the size of her family, and the small community in which they lived, their family did most things as a unit. This could be anything from attending grade school, sustaining their families land, traveling and going to church.

Her family moved to an urban city in a southern state of the U.S., where she completed her high school education, and two years of higher education. At this point, she branched out a little from her family and married a man in the armed forces, whom she said was a great companion and best friend until the time of his death. Together, they had six children, to which seven grandchildren were born. Similar to her own upbringing, she reared and cared for a rather large lower-middle class family. However, due to her husband's military status, their family moved around quite a bit. Further, she worked some menial jobs because of the constant moving, but ultimately owned a bakery with 
her husband after he retired from the military. Upon her husband falling ill, she became a family caregiver; caring for grandchildren, nieces, nephews. She also did most of the cooking in her household as two of her children, and their children lived with her.

\section{$\underline{\text { Participant } 2}$}

Next, there is the grandmother that was given the pseudonym "Lollie." During the interview, she stated that she was "66 years young". Lollie had a peanut butter complexion, with a short, grey haircut. She had a professional sass about her; she was very professional and precise about how she answered the interview questions but sometimes her speech came off as a little snarky.

Similar to the first grandmother, she also had a rural upbringing, but with a very different family structure. Specifically, this grandmother only had one other sibling, a brother, and she described her family growing up as middle class black people. Thus, she was fortunate enough to complete a bachelor's degree in English Literature and became a school teacher. Her educational experience pulled her away from her family and to a major, metropolitan city in the south where she began her career.

Within two years of her career as an elementary school educator, she met her husband at church. After six years of marriage, they conceived a son, and three years later, a daughter. They were a very close-knit unit, very similar to her family growing up. However, given their urban surroundings, in an ever-growing city, they allowed their children a little more freedom, and were able to engage in activities that were not available to her and her family during her upbringing. Her daughter blessed her with one granddaughter, that was loved abundantly by their small family. Given that her daughter was a single mother, she retired from being an educator to help solidify a stronger 
foundation for her granddaughter. About fifteen years after the birth of her first granddaughter, her son graced their family with another baby girl, that she essentially provided daycare for until she went to pre-school.

\section{$\underline{\text { Participant } 3}$}

The third grandmother interviewed was also 77 years old, and she was given the pseudonym "Mama Tude", due to how feisty she was during her interview. Mama Tude had a very dominant and assertive tone to her speech. She stood quite tall and had a short haircut as well. Further, she presented a no-nonsense demeaner as she was very quick and direct when answering question. Her answers often followed with a blunt "what else?"

Furthermore, she grew up in large southern city, where she spent her entire life. Her mother was a single mother of five. Mama Tude, being the second of the five, but the eldest girl took on many responsibilities to help her mother once her father passed. Specifically, when they were not in school she and her older brother worked in order to help supplement their mother's income. Mama Tude also helped with cooking and cleaning up after her siblings. Fortunately, she was able to get a break over the summers, because they always spent the summers with their grandmother.

Upon the completion of her high school education, she became a piano teacher at a local community center, while still keeping close to her family and supporting her mother in any way she could. Due to the support she provided for her mother, she was unable to attend college right after high school. However, she met her husband at the community center, as he was a youth basketball coach with the center. They married four years after meeting one another and had two children of their own, while raising a son 
that he had from a previous marriage. Altogether, she has eight grandchildren, including step-grandchildren, and five great-grandchildren. She helped care for grandchildren, especially her granddaughters while her daughter worked, but never allowed her responsibilities as a grandmother keep her from her dream. At the tender age of 61 , she finally completed a college education in music, in order to expand her career as a piano teacher.

\section{Participant 4}

Following Mama Tude's interview was an interview with a grandmother that was given the pseudonym "Joy." She is a young 64 years old and described herself as experienced in many areas of life. She was a fair-skinned, sweet lady. She seemed to speak at a million miles an hour and she knew she talked fast because she would often check to see if I understood what she said. However, she had a very joyful demeaner, as she smiled and joked a lot throughout the interview.

She described her hometown as very rural and considered herself to be a country girl. She grew up on her family's farm, where they harvested and sold blueberries in a small mid-western town. Her parents were married and had three other children. Further, her parents' home and her paternal grandparents' home were right across the road from one another. Thus, her family, extended family included, spent a lot of time together; tending to their family's land and animals, harvesting and cooking together. Of course, they spent a lot of time at the church, as it was the center of their community in such a small town.

Upon completing high school, she left her rural hometown to explore an urban life. She was quite adventurous, holding many jobs within the housing authority. 
Currently, she is a compliance manager with the housing authority. She was a single mother of three children and from her relationships, acquired three step children. This was very different from her parents and grandparents, as she lived in an urban city and never married. However, she took care of her family, regardless of trials and tribulations. Furthermore, she was also very influential in her grandchildren's lives, especially the girls, maintaining custody of three of them at some point in their lives. She suggests that she has a revolving door, in welcoming her children, grandchildren, extended and fictive kin into her home.

\section{Participant 5}

The fifth grandmother interviewed was given the pseudonym "Sissy", and she is 72 years old. She had a mocha-brown complexion and was kind of petite. Her hair was salt-and-pepper gray and shoulder length. Her interview was interesting because she just talked as if we were having girl talk at lunch. She was pretty talkative and addressed me as if I was her "sister-girl."

Similar to some of the other grandmothers interviewed, she too had a small-town, rural upbringing. She comes from a two-parent household, with six other siblings. Sissy suggested that she lived a good life, with great parents. Further, they lived in a pretty close-knit community, where the collectivism of kinship was highly enforced. In 1956, her family moved to a more integrated city, in which she attended an integrated school for the first time and experienced covert racism within the educational system.

Yet, she persisted, and she continued with her education until she graduated from high school. After high school, she worked in one of the first black-owned boutiques in the downtown area of the city. Following her job at the boutique, she became a life 
insurance representative, where she met her husband who also worked for the same company. Very shortly after that, she got married at age 19 . Her and her husband, had two sons, and she worked as a housing authority representative and a property manager throughout the years. Her sons graced her with two grandchildren, one grandson and one granddaughter. Further, she has created an open-door policy with her grandchildren, in order to allow them the comfort to speak with her about anything. From very young ages, she suggested that this has strengthened her relationship with her grandchildren, especially her granddaughter.

\section{Participant 6}

Finally, the last grandmother interviewed is an 87-year-old treasure, who was given the pseudonym "Grand" because she exhibited such a grand interest in the research being conducted and a willingness to participate. She had her pulled back into a low, grey ponytail. She was a heavier-set lady and dark skinned. She was a sweet lady with a very calming demeaner. She spoke slow and soft, but with confidence.

She was born in a small, rural town, but grew up in a major metropolitan city in the south. Her mother was not married and only had one other child, a son that was younger than Grand. Given her mother's rural background, she suggested that her mother showed her and her brother a lot of tough love in order to prepare them for life in the city. Her mother also had sisters that helped to raise Grand and her brother, including her mother's youngest sister, who Grand suggested was more of a big sister to her than an aunt. However, they lived a pretty urban lifestyle, in which she suggested there were much better job opportunities. 
Moreover, she was barely able to complete high school because she had to help support her household. Before she completed high school, she became a domestic worker in the inner city just like her mother. However, once she finished school, she moved on from that occupation. Specifically, she worked for a popular technology company that designed things such as calculators and other electronics, where she would later retire. Altogether, she raised five children, three of her own, as well as a niece and a nephew alone, given that Grand never married. Further, she was also very influential in the rearing of her grandchildren, as well as the children of her niece and nephew, since they all lived with her at some point during their childhood.

\section{Descriptive table of participants}

\begin{tabular}{|l|l|l|l|l|l|l|}
\hline $\begin{array}{l}\text { Participant } \\
\#\end{array}$ & Pseudonym & Age & Education & $\begin{array}{l}\text { Family } \\
\text { status }\end{array}$ & $\begin{array}{l}\text { Work type } \\
\text { (s) }\end{array}$ & $\begin{array}{l}\text { Region/ } \\
\text { State } \\
\text { code }\end{array}$ \\
\hline (P1) & Dottie & 77 & $\begin{array}{l}\text { 2 years of } \\
\text { higher } \\
\text { education }\end{array}$ & $\begin{array}{l}\text { Married, } \\
\text { with six } \\
\text { children }\end{array}$ & $\begin{array}{l}\text { Military } \\
\text { wife, menial } \\
\text { jobs, bakery } \\
\text { owner }\end{array}$ & South \\
\hline (P2) & Lollie & 66 & $\begin{array}{l}\text { Bachelor's } \\
\text { degree }\end{array}$ & $\begin{array}{l}\text { Married, } \\
\text { with two } \\
\text { children }\end{array}$ & Teacher & South \\
\hline (P3) & Mama & 77 & $\begin{array}{l}\text { Bachelor's } \\
\text { degree }\end{array}$ & $\begin{array}{l}\text { Married, } \\
\text { two } \\
\text { children, } \\
\text { one step } \\
\text { child }\end{array}$ & Teacher & South \\
\hline (P4) & Joy & 64 & $\begin{array}{l}\text { High } \\
\text { school } \\
\text { education }\end{array}$ & $\begin{array}{l}\text { Never } \\
\text { married, } \\
\text { had two } \\
\text { children }\end{array}$ & $\begin{array}{l}\text { Housing } \\
\text { authority }\end{array}$ & $\begin{array}{l}\text { Mid- } \\
\text { west }\end{array}$ \\
\hline (P5) & Sissy & 72 & $\begin{array}{l}\text { High } \\
\text { school } \\
\text { education }\end{array}$ & $\begin{array}{l}\text { Married, } \\
\text { with two } \\
\text { children }\end{array}$ & $\begin{array}{l}\text { Insurance } \\
\text { representati } \\
\text { ve, property } \\
\text { manager }\end{array}$ & South \\
\hline
\end{tabular}




\begin{tabular}{|l|l|l|l|l|l|l|}
\hline (P6) & Grand & 87 & $\begin{array}{l}\text { High } \\
\text { school } \\
\text { education }\end{array}$ & $\begin{array}{l}\text { Never } \\
\text { married, 3 } \\
\text { children } \\
\text { of her own } \\
\text { plus a } \\
\text { niece and } \\
\text { nephew }\end{array}$ & $\begin{array}{l}\text { Domestic } \\
\text { servant, } \\
\text { technology } \\
\text { company }\end{array}$ & Mid- \\
\hline
\end{tabular}

\section{Method of Data Collection}

The data for this study was collected through a series of in-depth, semi-structured interviews from select African American grandmothers. Due to the conversational style of the interviews, the interviews lasted anywhere from 30 minutes to an hour and fifteen minutes. Furthermore, the interviews took an oral history stance as these grandmothers not only described their experiences, but what women like them have been known to do historically through contemporary times. These experiences and perspectives are important to capture because they help to understand the ways in which the intersection of race, class, and gender have impacted the realities of the women and how the grandmothers navigate the sustainability of their families.

\section{Interview questions}

The interview questions were created around the overarching research objectives. Questions focused on the historical and contemporary roles of African American grandmothers; the social stereotypes of the strong black woman and the black matriarch as they pertain to the roles and responsibilities of African American grandmothers. Additionally, the grandmothers were asked whether the portrayal of strength in black women, specifically grandmothers is a myth, a defense mechanism, a true characteristic of black women, or if all are true in regard to African American grandmothers and their portrayal of strength? Thus, the research questions are sectioned into themes that match 
the overall research objectives. Twelve general questions were asked in total with followup probing questions. The research questions, and their themes are as follows:

\section{Historical and Contemporary roles of African American grandmothers}

Q. 1. Tell me about yourself, where were you born and where did you grow up?

Q. 2. What about the women in your life coming up, who are they and what kind of roles do you feel they had in your upbringing?

Q. 3. Do you feel as if these women were influential to you?

- If so, in what ways did these women impact your life as it pertains to being a black woman, mother and grandmother? Or in general?

Q. 4. From your experiences, and those that you know, what are some of the roles and responsibilities that black and African American grandmothers currently have in the nuclear or traditional family, as well as the extended family?

Q. 5. What about your grandmother, and other grandmothers you knew growing up, did they have similar roles and responsibilities in the nuclear or traditional family as well as the extended family?

Q. 6. Do you feel like your roles and responsibilities, and other grandmothers you know, have been influential in the survival of the black family?

- What about fictive kinship? Do you care for any children or grandchildren that are not your own biologically, by law or that have been legally adopted into your family as if they were a part of your family?

Q. 7. What about African American grandmothers' roles in the communities? Are there any specific roles that you or those you know hold in your communities? 
- What about your grandmother coming up, did they hold any specific roles in their communities?

\section{Strong Black Woman and Black Matriarch}

Q. 8. Are you aware of the portrayal of black women, particularly grandmothers, as strong matriarchs?

- If so, how has the perception impacted the expectations and roles you have as a grandmother?

- If not, do you perceive yourself as a strong black woman who is the head of the family?

Q. 9. Do you feel the images of being a strong black woman or a matriarch causes your family members to view you in an unrealistic way?

Q. 10. From your experience, how have these images impacted the way in which you view yourself?

\section{African American grandmother's portrayal of strength}

Q. 11. Tell me about the emotional or traumatic aspects of carrying this load and having these expectations, roles and responsibilities placed on you.

- Given the expectations of being a strong black woman or strong matriarch, are there time you felt overwhelmed with some of your responsibilities or the expectations of your family members?

i. How did you manage the difficulties?

Q. 12. In what ways do you feel you have had to sacrifice or compromise yourself for the sake of your family?

- How did you or do you cope? What are some things you do when coping? 
- Generally, has there been a support system for you when your responsibilities become too much?

- Who have been people that you can call on when you feel like you may not be able to accomplish something expected of you or even just feeling down?

\section{Data Collection}

In order to conduct the interviews, a home visit was made to each participant at their respective residencies. For each interview, a tape recorder was utilized to capture the full interview, while strenuous notes were taken if the participant felt comfortable with the researcher also taking notes. Two of the six participants did not feel comfortable with the researcher taking notes during the taped interview. These two participants agreed to being tape-recorded, however, note taking made the interview seem like more of an interrogation than a conversation. Therefore, once those particular interviews were completed, the researcher made quick notes from memory.

Though interviews were the primary method of data collection, data was collected from secondary resources, such academic journal articles and books. Moreover, the use of secondary resources was critical to the research in that it helped to form the research objectives by revealing the gaps in prior research regarding the experiences of African American grandmothers. Further, secondary resources or prior literature is important to refer back to during the data analysis, as well as the conduction of the findings of the research.

\section{$\underline{\text { Data Analysis }}$}


The recorded interviews were transcribed by the researcher. The length of the interview determined the amount of time necessary for transcription. However, transcription took anywhere from two to five hours. Along with the notes from the interviews, or those recorded following the interviews, the transcribed interviews were then organized and sectioned according to the overarching themes of the research objectives, by participant. Though interview questions were already sectioned in regard to the research objectives, the transcribed interviews had to be organized in accordance to the themes. Because of the conversational style of the interviews, questions were not always answered in order.

The findings were then organized around similarities and variations of experiences and perspectives. This allowed for comparison the experiences of the grandmothers interviewed, along with the findings of prior studies on the black grandmother.

\section{Limitations of the Study}

There were several limitations that were presented throughout the duration of the study. One of the primary limitations was the sampling of participants. Specifically, given the process of referral in snowball sampling, some of the grandmothers referred were not willing to participate or were not available to meet for an interview. Thus, other grandmothers had to be recruited. Unwillingness to participate alludes to the mistrust of scientific research by members of the African American community. However, it could also possibly be due their busy lifestyles. Another key limitation would be that sometimes the participants were not always able to quickly recall memories to address the questions about their upbringing because of their ages. Sometimes, the participants 
admitted to not being able to recall certain things at all or needed a little extra time to gather their memories. 


\section{CHAPTER 5: FINDINGS}

\section{Historical roles of African American grandmothers}

One of the initial questions in the interviews discusses the roles and experiences the respondents recalled of their own grandmothers. This question was utilized to capture some of the historical roles that black grandmothers possessed. Ironically, many of the respondents had very similar ideas, and memories of what their grandmothers did and meant for them. For example, those that were fortunate enough to have met their grandmothers recall spending a lot of time with them, whether that be during the afternoon, in the summer, or just on the weekends. Often, for a few of the respondents, this time was either spent picking and harvesting food, cooking and learning to cook, or just fellowshipping around the dinner table at their grandmother's homes. Joy (P4) recalls, "I remember picking blackberries with my paternal grandmother, then turning them into preserves and breads with my grandmother in her kitchen."

Furthermore, the respondents that had a relationship with their grandmothers remembered their grandmothers gathering them, their siblings, cousins and close family friends, and telling them stories of their experiences, as well as family histories and culture. Grand (P6) for example stated, "My granny would get all the kids together, and we would sit around her and listen to all the stories of her coming up. She had some fantastic stores to tell us." In recollection of the stories that her grandmother told her as a child, Dottie (P2) also mentioned her grandmother telling stories of her great- 
grandmother, as well as her great-great grandmother. "Grandma told me lots of stories and lessons. She always told me stories about her mother and grandmother and I was just like them in some ways."

Likewise, the respondents not only recalled some of the stories that were told to them by their grandmothers, but also the lessons, morals and values their grandmothers instilled in them and that were entrenched in many of the stories told. For example, the respondents learned from their grandmothers to be independent, disciplined, loving, and open-minded. They were also taught the importance of family and taking care of families. Joy (P4) specifically remembered her grandmother being somebody that she could talk to about anything, with a certainty that she would not be judged. "With Grandma, she was an influence on me being so open minded and allowing people to talk to her about things they couldn't talk to other people about."

In accordance to being independent, Grand (P6) tells about how her grandmother raised nine children on her own after her grandfather passed, so it was always important for Grand's grandmother to instill in her children and grandchildren how critical it is to be independent. Of course, along with the lesson of independence also came the lesson of strength, as many of the respondents recalled. The participants credit not only their grandmothers, but also mothers, aunties and other influential women in their lives for instilling the importance of strength for black women. As mothers and grandmothers, black women often have to carry the load of socializing children, while working and experiencing discrimination in the work place. Thus, the participants' mothers, grandmothers and other influential black women informed them of the necessity of strength for and by black women. 
Unfortunately, two of the respondents did not have the opportunity to meet their grandmothers. Such as Sissy (P5), but she specifically recalled the stories her parents and siblings told her of her grandmother, and she knows that her grandmother was a loving and Godly woman. Lollie (P2) also did not have the opportunity to know her grandmother, but she spoke of how influential her mother was in her upbringing and the ways in which she raised her own children and grandchildren. In fact, most of the respondents talked about the influence of their grandmother, and mother especially in regard to the influential roles they had or have in the lives of their children and grandchildren. Along with mothers and grandmothers, the participants discussed the influence of other women, such as aunties, and women from their churches and communities.

Grand (P6) spoke very highly of her mother's youngest sister; she insisted that this particular auntie of hers had very strong influence on her, as this was the auntie she moved to the city with to help support her family that was still in the country. Aunt V, as Grand called her, pushed Grand to go as far in life as she could, to go to college and to make a good living for herself. However, Grand suggested that all of her aunties, mother, along with the lessons from her grandmother were very influential. In speaking on the influence they had on her collectively, Grand states,

They didn't have anything, you know? But they worked hard, whatever job they had, they knew how to stretch them little pennies. They knew how to manage what little money they did have, so they could provide for their family.

Joy (P4) and Sissy (P5) spoke very highly of the women from their churches that were influential in their upbringing. Considering Sissy was never able to meet her grandmothers, she spoke of her church aunties that helped her mother keep an eye on her. 
She stated, "All my aunties, they used to drag me everywhere with them. Trying to teach me and prepare me to be a working girl." Likewise, Joy also spoke of the women from her church that were very influential in how she carries herself as a woman.

My church mothers, see they kept me busy and out of trouble. They taught me to be fearless and speak up, that's why I can do a little public speaking now. Made sure I carried myself lady like and kept them lil boys from round me.

\section{Contemporary roles and perceptions}

In regard to contemporary roles and perceptions, there were similarities across the African American grandmothers, but some of them had different relationships and roles in their grandchildren's lives. As a contemporary African American grandmother, Lollie's (P2) role was to support her granddaughters, help them in any way possible, similar to some of the other grandmothers. However, she felt she was very influential in her granddaughter's younger years because she was her primary source of transportation to and from school, summer programs, and to peer's houses. This was very similar to the one of the primary roles Joy (P4) had as grandmother, describing herself as the "taxi-cab and the teacher." Mama Tude (P3) also transported her grandchildren many places, mainly to expose them to different things. She stated, "Because so many younger parents would rather spend money on their kids than spend time, I make sure I spend quality time with mine and expose them to different experiences."

However, the other three respondents, Dottie (P1), Sissy (P5) and Grand (P6), were more homebodies with their grandchildren. In other words, they were more concerned with spending time with their grandchildren in the home. Grand suggested that she did not always have the financial means to do for all of her grandchildren equally. One of the main ways Grand spent time with her grandchildren was through story time, 
similar to what her grandmothers did for her as a child. Sissy, on the other hand felt that spending quality time, and open communication is a central aspect of grandmother roles. She spoke of inviting her granddaughter over just to have lunch and talk about the different stages of life. Further, Dottie specifically spoke about the importance of not allowing her children and grandchildren to roam freely around their community, but keeping them close to home and having activities they could do in the house, such as cooking and game nights. Moreover, keeping her children and grandchildren close to home was extremely important to Dottie given that this is how her mother and grandmother raised her and her siblings; they kept them close to home, didn't allow them to eat at other people's homes, and always knew their location if they were away from home.

Interestingly, all of the grandmothers attempted to mimic the socialization characteristics of their grandmothers, mothers, and other influential black women in their life. A common theme that seemed to exist in all of their experiences as African American grandmothers is the teaching of positive morals and values, whether it be from these grandmother's wisdom and experiences, or the same morals and values that mothers, grandmothers, aunties, church and community women instilled in them. Most of the respondents recognized the wisdom they have accrued from their experiences of sorrow, and triumph. So, they feel obligated to try to pass on their knowledge to their children and grandchildren. Thus, in trying to be the best influence for her children and grandchildren, Lollie (P2) stated, "I try to teach my children and granddaughters what's right from wrong from my knowledge, cause I've been there and done that." Mama Tude 
(P3) spoke generally, not only of her instilling good morals, but what she felt to be the roles of most grandmothers. She stated,

Most grandmothers, see we try at least, we try to teach kids to respect values, authority, because the younger generation don't instill this to their children. I try to instill the principles and values I grew up with, but sometimes I think I'm trying to overcompensate cause I recognize the steps I missed as a parent, so I try to make sure that I don't miss those same steps helping to raise my grandchildren and great-grands.

Though all of the respondents were religious or spiritual, Grand (P6) and Sissy (P5) were very adamant about being a spiritual role model for their children and grandchildren. Grand remembered the strong Christian beliefs that her grandmother instilled in her, so she tried to instill the same things in her children and grandchildren. She states, "I teach my grandchildren to be truthful, courteous, and kind, cause that's what the Lord wants." Sissy felt it was important for her to make good choices so that her grandchildren have somebody positive to look up to. Specifically, she says, "I try to be aware of what I'm doing and who's watching. I try to make good choices so that my grandchildren can see God in me."

In reminiscing on what her grandmothers did for her, in comparison to her role as a grandmother, Joy $(\mathrm{P} 4)$ realized that though she tried to teach her grandchildren similar morals and values, she had a very different experience as a mother and grandmother. She explained,

I have not been the same kind of grandmother to my granddaughters that my grandmothers were to me. It's a different time, and my life wasn't like my grandmothers lives. They were married, and I was single most of my life. They had husbands to take care of them, I didn't.

She also realized that her experience as a grandmother was very different because she did not live in close proximity to her granddaughters, but she still wanted to be a constant in 
their lives. Similar to some of the other grandmothers, Joy admitted to overcompensating for her children's mishaps in raising her grandchildren. One of her sons has been incarcerated, so for his daughters she always wanted to let them know that she was there for them and let them know that she loves them. Further, she tried to make sure that she kept them as much as she could and took them to visit their dad.

There were time I went and got my grandbabies and kept them for the weekend. I knew I wanted to be active in their lives, even though I was fifty miles away. I just wanted to be there and be present. Let them know that I love them. I just wanted to make sure they were okay, and I think that's what my grandmothers would have done had they been a single parent that raised their kids by themselves.

Moreover, the respondents all wanted to push their grandchildren to explore life and go as far as they could go in some aspect or another. A common theme that presented itself would be the pursuit of an education. Many of the grandmothers felt higher education was not only important for their grandchildren, but also important in sustaining their families. Grand specifically felt it was critical to teach children to be lifelong learners and to set high goals and standards for themselves.

Everyday, it's something new to learn. I stress to every kid to go to college and learn. A grandmother can tell kids that they may not have gone to college so they can see and stress the importance of going to college.

Lollie (P2) was also very vocal about pushing her granddaughter to go to college, as well as supporting her during that journey. She held that, "I have been influential in emphasizing the importance of college education to my grandchildren because I believe that college is a necessity for the survival of our families and communities."

Mama Tude's (P3) perception of education was very interesting. She felt that pursuing an education had always been a goal for her, but life always derailed her from 
pursuing one, whether that was having to work to help her family, caring for her parents before their transition, or aiding with the socialization of her grandchildren and greatgrandchildren. However, she never let the dream of being college educated slip away from her. "I think I was 61 years old when I graduated from college. Cause I was determined to get my degree. It brought me satisfaction because I wanted for myself, and to show my girls if I can do it, you can do it.” Thus, she wanted to let her granddaughters know that life happens, and things may not always get done how one might expect, but they can achieve whatever their hearts desire.

Many of the respondents spoke about the roles and responsibilities they felt all African American grandmothers had in general. Grand (P6) recognized that some grandmothers may not always be able to do much for their grandchildren, due to dependency, illness, and old age. However, she felt that black grandmothers were family teachers, whether they were teaching their children and grandchildren about their family histories and cultures, teaching them about the different phases of life, or teaching them to be better than they were. Sissy (P5) felt there was a different kind of energy that comes with being a grandmother, because one has more time to spend on the important things. Moreover, Lollie (P2) felt that grandmothers have been influential in keeping families together. "We have been the glue when some members of the black family are just beginning to learn how to support one another. See, we know how important it is for our families to stick together and support one another."

Along with the theme of keeping families together, many of the respondents spoke about what they have seen other black grandmothers experience, even if it was not of their own experiences as grandmothers. Of course, many of them recognized the 
similarities that they had with other black grandmothers, but they also mentioned things specific of their close friends' experiences as grandmothers. For example, a few of the respondents acknowledged that many black grandmothers are raising their grandchildren. Mama Tude (P3) stated, "Grandmothers have to discipline their grandkids because the younger generations put are putting their kids off on the grandmothers. So, a lot of grandmothers are raising their grandchildren." Sissy (P5) also recognized this trend with African American grandmothers, saying, "So many of my friends are now raising their grandchildren and it's difficult because we're much older now." Though she empathizes with the grandmothers that have to take on the task, she realizes how fortunate she is in saying, "I'm truly blessed that my grandchildren have their parents."

Yet, according to the respondents, this is not the only way African American grandmothers have been influential in keeping their families together. Many of the respondents spoke of the importance of fictive kinship in their upbringing, as well as in their current roles and responsibilities. Specifically, fictive kinship can be described as social or familial ties that are not based on biological relation or marriage, while kinship can be considered the absorption or adoption of extended family into one's household (Littlejohn-Blake \& Darling, 1993). For instance, Joy mentioned a whole host of stepgrandkids, half-grandkids, and adopted grandkids. Excitedly, she says,

I grew up in a family of halves and steps, so I don't know any different. I had cousins that weren't cousins, but I was told they my cousins, so they my cousins! But I'm glad because that just means we were taught to be inclusive.

Joy's experiences of the uses of extended and fictive kinship ties is symbolic to the idea that it takes a village to raise a child. Grand (P6) also raised a niece and a nephew, along with her own biological children, and then preceded to raise the son and daughter of the 
niece she raised when her niece died. She recalled that was how she was raised and often family members and outside fictive kin members help raise children. With an almost nostalgic smile, she said,

I don't know, it just seem like a common thing. That we love each other and help each other. If it's another family that isn't related, black people, we just reach out to them and help them, and bond with them. I don't know if that's just a thing that runs through black people, but that's just the way it is.

Thus, many of these fictive kinship relationships were formed throughout the community bonds that the women built. When queried about the community roles that black grandmothers had, every single respondent mentioned the church as a community center for them. Grand suggested that she, her grandmother, and other black grandmothers she was familiar with held a number of church responsibilities. They cooked for the churches and were on the bereavement organizations to reach out to families in the time of death. Dottie (P1) also suggested that church was her number one activity outside of her family. She also teaches her grandchildren to be spiritually involved, exposing them to the many activities that go on at her church. Further, Joy (P4) also spoke of being a church mother to some of the younger women at her church, just as she had church mothers growing up. Sissy (P5) suggested that she spent her week in church, at least four days a week at the church for various services and activities.

Only Grand, who is the eldest at 84 years-old, mentioned different roles that she, and other grandmothers have had in their community, besides church roles. Grand essentially suggested that black grandmothers have been midwives, doulas, and nannies by assisting younger generations care for their children, during and after birth. Furthermore, Grand recalls some grandmothers being activist in their communities, by informing people of political and social issues. Lastly, as a grandmother in the 
community, Grand read to the people who either could not read or did not like to read. This demonstrates the differences in the roles that grandmothers had due to age differences.

\section{Strong Black Matriarch}

Given their various responsibilities within their families, as well as the roles of other African American grandmothers that they mentioned, it appears as if black women are aware of the idea of the strong black matriarch. Though many of the respondents had varying perceptions of what it meant to be a matriarch, or they all believed that black grandmothers are strong black matriarchs who play a major role in the sustainability of African American families and communities. In this section, the respondents' conceptualization of what it means to be a strong black matriarch, as well as the expectations that come with being the matriarch of the family, are discussed.

As mentioned, the respondents believed that most African American grandmothers are the strong black matriarchs of their families. In reference to black grandmothers as matriarchs, Dottie (P1) stated,

Considering all that some of us, and those before us, had to go through, we always survived and still made things happen. No matter what, we always make things happen. We live for our families and just want to love all of 'em and see 'em happy.

Joy (P4) suggested that she considered black grandmothers to be family matriarchs because she always heard people talk about their grandmothers, and what their grandmothers meant to their families. She considered black grandmothers to be one of the primary foundations in not only the grandchildren's lives but the whole family in general. Further, when asked if she was aware of the idea of black grandmothers as strong black matriarchs, Sissy (P5) stated, 
We are strong black matriarchs and we know we have to carry the ball. We know that we have to be there to get things done. We do things to protect our families, we struggle but we just have gotta stay focused because we have to be prepared.

An interesting theme regarding be strong black matriarch was the transference of knowledge between generations. Specifically, Lollie (P2) felt that her job as the family matriarch was not just to teach but also to listen and learn from her granddaughters. "Just as much as kids learn from their grandmothers, we learn just as much from them." Sissy and Dottie also emphasized the importance of creating an open line of communication, so they could influence their grandchildren, but also for them to be influenced by their grandchildren and social times. Similar to their idea of open communication, Grand also felt it was necessary to learn for her grandchildren, as a means of continuing to be a lifelong learner and expanding her perception of how to care for her grandchildren given the times and their needs.

Mama Tude (P3) suggested that what qualified her to be the strong black matriarch of her family was her dedication to them. As a woman with many interests and hobbies, she felt it was more important to dedicate her time to her family than it was for her to give her time to other people and interest. She states,

There are a lot of things I could be doing, but I choose to spend my energy and my time tending to my kids, grandkids and great-grandbabies. That's always been my goal though. I take care of mine first. That's what my mama taught me, to take care of home first.

Joy (P4) was also very similar in her dedication to her grandchildren, even though she did not always get along with their parents. She also never allowed the fifty-mile radius between her and her grandchildren diminish her dedication toward them. However, she took pride in her grandchildren considering her authority over their parents, because she was aware of their feelings that if nobody could get things handled, she could. "I know 
when they need to call somebody they can depend on, they call me. I know some of them will call me quicker than they call they own mama."

All of the respondents recognized the expectations that come with being a strong black matriarch, however, they had not considered how these expectations impacted the ways in which they carried out their roles as grandmothers. Lollie (P2), for example, feels that sometimes she is viewed as if she has super powers, yet she acknowledged the difficulty in being viewed this way. She says,

But it gets stressful when you hold this kind of power and y'all don't listen to us because yall think we're ignorant of the times. Like I'm too old to know what's going on, but it's my job to still tell you right from wrong.

Joy (P4) is very similar to Lollie, as she realizes how difficult it can be to always be depended on by her granddaughters, but she credited her grandmothers for her ability to still be a force in her granddaughters.

If my granny hadn't gotten me, worked me, and kept me so often, I don't know that I would be as active in their lives. I wanted to keep my grandkids as often as I could cause my granny kept me.

Grand also had a very similar outlook on her duties as a family matriarch, giving credit to the women before her. She stated, "But had it not been for those women in my life growing up, I don't know if I would have been as strong as I was to do the things I did that my family needed."

Dottie's (P1) response was a little different. While the other respondents recognized that their children and grandchildren's expectation of them caused them to perform in a certain way, Dottie suggested that her children and grandchildren expectations of her had very little impact on how she performed her duties as the family matriarch. 
Both of my grandmothers and what they taught me has more of an impact on my roles, than my children. My grandmothers, they talked to me, and told me the things I should know with every age and stage of life. Granny would say, 'Come on sit down so we can visit for little bit.'

Further, she suggested that her grandmothers taught her about all of their experiences of being mothers and grandmothers, good and bad. So, she always go back to how she was raised if she needs a reference on what do with her family.

Furthermore, the respondents not only recognized the expectations and how it impacted their duties, but they recognized how such expectations affect the ways in which they view themselves. None of the respondents necessarily admitted to feeling incapable, but rather feeling as if they have to be better. Lollie (P2), for instance, stated,

My baby is looking up to me, so I have to do better and be better. When it comes to helping with discipline, I have to remember not to go too far but far enough to make sure that my influence is still strong, and I'm being understood.

Essentially, she had to find a balance within herself in order for her to be influential to her granddaughters. Mama Tude (P3) made a similar statement; she said, "They always think mama gone fix it, or mama can fix it. So, I gotta figure out how I can fix it for them."

Joy (P4) had similar perceptions of herself; however, she compared the kind of roles she had as a strong matriarch to her mother and grandmothers and realized that though she lived a different kind of life, she still exerted strength in her roles as a family matriarch.

I view myself more of a strong black woman because I didn't grow up the same way my mother and grandmother did. My life took a whole different trial being a single mother. But I learned from them how to scrap and how to save, and how to make something our of nothing. This came from grandma: You don't let nothing stop you, and if you can't do it, find a way to get it done. 
Basically, she knew she was strong, yet she realized that strength can mean different things depending on life circumstances.

\section{Sacrifice and care under the black matriarch}

The last section expressed why these grandmothers felt they needed to be a sign of strength for their families, whether it be because their families expected it from them, or they expected it of themselves due to the teachings of the women before them. This section will explore where some of the strength came from, or rather, the experiences that informed them that they were strong women. Further, this section will also explore the respondents' perceptions on sacrificing for their families, as well as the ways in which these women coped with strain of being a matriarch or just a black woman when they needed to.

All of the participants recognized how their life's journeys made them a little wiser every day. Thus, they also recognized the ways their wisdom allowed them to be strong, as well as influential in their children and grandchildren's lives. Lollie (P2) felt that her experiences allowed her to be more knowledgeable, she felt like she needed to pass her wisdom on to her granddaughters. However, she felt like she was not always heard, but her strength and wisdom permitted her to continue trying to instill certain lessons in her granddaughter because she knew one day she would need them.

It can be stressful trying to teach things to yall when yall don't want to listen or believe fat meat grease. But I keep on talking and giving the advice I give, even yall don't want to hear it or don't feel like yall need to know it, cause I know my voice will pop up in your head with my avdice when you need it or when you're ready for it.

Mama Tude (P3) felt it was important to pass on to her children and grandchildren to be there, and do for people, especially their elders while they are still alive. This was 
important to her because she put her life on hold to care for her parents before they passed, and she felt relief knowing that she took care of the people that took care of her. Essentially, she didn't have any regrets in their last days because she knew she did everything she could. Thus, she tells her granddaughters to make sure that they do their best to support her, their mother, and other grandmother.

The same relief I felt for doing all I could for my parents before they passed, is the same relief I feel now. Cause I see how my granddaughters help their mom when she has her sick spells. Whenever she has had to go to the hospital, they were there. I know I've done well by them.

Grand (P6) had a very holistic view of the strength and wisdom she has accumulated. She feels that she was meant to get all of the knowledge she could for a specific reason. She experienced so much sorrow, burdens, and triumphs, but she never let anything keep her from doing what she was supposed to do as a mother and grandmother. She said, "As grandmothers, we're put here for some reason, and I remember that when times get hard. I know when I've done what it is I've been put here to do, I'll go on home." Grand encountered the death of her mother and the niece she raised in the same month, and though she mourned, her strength allowed her to step up and help raise the children of her niece, as well as be of support to her family as they mourned the losses. "Even though we strong, sometimes we have fears, and maybe doubts. But if we stay strong and stay connected to the Lord, He'll see us through.” Sissy (P5) acknowledged her first sign of strength as a young black girl in a newly integrated school. In recollection of having rocks thrown at her, and feeling unwelcomed, with a shrug, she stated, "Got through that" and moved right along in the interview. The shrug was not to say that that experience was not traumatizing in some ways, but rather an acknowledgement that they tried to break her and could not. Her experience granted 
her the wisdom of knowing that there is more to life; reminded her to always look at the bigger picture. Thus, she felt obligated to let her children and grandchildren know that “Life can hurt sometime but you don't live life for yourself. You muscle through that hurt because you can't get caught up in your own sorrows, when somebody else could need your help."

Joy (P4) felt as if she didn't recognize her strength until she left her rural community and moved to the city. She left her small community, her family and the church she had grown up in to explore an urban living. However, as a single mother, life did not always play out the way she had hoped.

I really didn't have anybody to depend on. You find out real quick how strong you are when there is nowhere to go. I've been homeless a couple of times in my life. I've been with somebody that's abusive, and that was hard to get out of because I didn't have any family around me. But I learned how to ask questions to myself and for myself. I had to try a lot of different things but when I found something that worked, I did that. If you have a bad experience, try to learn the lesson from the experience so you don't repeat it.

Joy essentially found her strength in just living and learning. The wisdom she gained from her experiences allows her to build up the strength to be there for her grandchildren, no matter the distance because she's been alone and she doesn't want that for them.

Dottie's (P1) idea of strength was a little different. In this section, she mostly spoke specifically of what she has done for her children and grandchildren. However, she felt her strength came from the lessons of her grandmothers, being able to speak to her mother when she was in need, as well as having a very supportive husband. She suggested that her and husband did everything together before he passed. Yet, even after he passed, she still felt it necessary to continue with the same role she had when he was alive. "I had to still be there for my family, even though it was difficult now. But they 
needed their mother, and that's when I knew I was no longer striving to be a matriarch, but that I had become it." Thus, she gained a true understanding of her strength once she understood that people who depended on both, her and her husband still needed her more than ever now that he's gone.

\section{$\underline{\text { Social-Psychological Experiences }}$}

All of the participants situated their social psychological experiences within the context of sacrificing and the impact on them or their psyche. Sacrificing was just a part of being a mother or grandmother. One of the common ways the women sacrificed for their families was in a financial aspect. Lollie (P2) recalled sacrificing her house note to ensure that her daughter could take a trip with her school. Further, when asked about the ways she sacrificed for her granddaughters, she suggested that “

Everyday is a sacrifice for them. I still work so that I can still buy things for them. But sacrificing comes easy when you love people. It comes naturally. Sometimes we don't' even think about it, we just do it.

Mama Tude's (P3) sacrifices has already been mentioned in previous sections, as she discussed caring for her parents in their time of need, as well as caring for her granddaughters when their mother would get sick sometime. However, she also acknowledged the monetary and time sacrifices she made for family. Suggesting that sometimes she had to sacrifice time at work to spend time with her family, and other times she sacrificed time spent with her family in order for her work to provide. She stated, "There are of a lot of things I had to sacrifice, but I don't hold no grudge about it, because I did it cause I want to." Again, emphasizing that she did what she could so that she does not have to any regrets in the end. 
Grand (P6) made a very similar statement in regard to the financial sacrifice she made for her family. She sacrificed spending time with her family so that she could get a second job in order to make sure everyone was taken care of. Ironically, she did not confess that was a mistake, but she felt as if time spent with her family was more important. "Actually talking to them, and engaging with them is what I missed working as much as I did."

Similar to Mama Tude, Dottie also sacrificed by caring for her mother before her transition. "The doctors told me to put her in a home, but I told them no. I got it." She remembered helping to care for an aunt before she passed and she knew that with the support of her siblings, husband and children, that they could take care of her mother. “All of us together, we'll do it. And that's what we did." Unfortunately, she didn't speak much on the sacrifices she made as a grandmother or mother, besides having to divide the attention that she would have given to her children with her sick mother.

Sissy (P5) felt that black women sometimes sacrifice their sanity for their families. In this section of the interview, she spoke again about always having to be the ones to see the bigger picture and live for everybody else.

You got to be the one to keep things going. I'm sure black women feel like one day we won't have to have all of this on them. Maybe we'll get to just enjoy the day,

Further, she acknowledged how black women, as mothers and grandmothers, have the whole family depending on them. While they rarely have anyone to depend on when they are in need. "We know that we have to be there to get things done, and sometimes we have to suffer in silence to make sure we're not seen as weak or incapable." 
Dottie (P6) followed suit in having to suffer in silence. She suggested that if she and her grandchildren both need separate things at the same time, she always got them what they needed first. Even when she was unsure of how she would get what it was she needed for herself. She recalls having to give herself pep-talks when she was alone in the midst of fear and doubt. Also, working with the housing authority, she recalled having to give similar pep-talks to some of the mothers she encountered. She would tell them,

Cry when you gotta cry. Withdraw when you need to but don't stay there. Don't give up, don't give out. When your kids need to see somebody that strong, they need to see you. If they see you broke down, crying all the time, what do they have for hope? You're their hope, you're their strength. They don't need to see you broke down. If you need to cry, go somewhere else and cry. Don't cry in front of them cause they need to see you strong, so they can be strong. When you have weak moments, don't have them in front of your children.

Which is very similar to Sissy's insistence that black women have to suffer in silence.

\section{Coping Strategies}

Given the amount of stress that comes with being a mother, grandmother, strong black matriarch, or just a black woman in America, there has to be a time, even if just for a second, that these women take to decompress. Furthermore, silent suffering that some of these grandmothers is definitely something in which someone would be in need of something or someone to help them process why and how they have placed under such conditions. Thus, in this section, the various ways in which these women choose to cope will be explored.

Most of the grandmothers shared similar ideas of coping with their roles and responsibilities as strong black matriarchs. Four of the respondents spoke specifically to turning to spiritual or religious practices when they need guidance or need to release.

Lollie (P2) suggested that God will always make a way, she stated, "He never puts more 
on me than I can bare, so when I'm doubting myself, I pray because I never doubt God." Grand (P6) asserted that she trusts that prayer works, and her prayers will be answered. She said, "I put all of my trust in God, and when things get hard I pray to him. It's important that I keep my faith intact." Sissy (P5) referenced the experiences of black women in general, suggesting that black women had to be Godly women because they knew everyone is depending on them. "How would we get through our day to day without God? Praying and asking for guidance is a primary source of hope for us. We gotta have God in our life." Joy (P4) also felt that prayer was one of her primary means of coping with her responsibilities as a mother and grandmother.

Along with praying, Joy also felt that releasing by crying was a way for her to cope. She stated that, "Crying allows you to let some of that out." She used to talk to friends as a coping mechanism sometimes. Especially when there were only a few friends she could talk things out with. Joy also suggested that treating or rewarding herself was a form of coping for her.

Lollie (P2), along with prayer, suggested that spending money was a way that she coped. "When my husband passed, some days I would just have to find something to buy. Furniture, clothes for me, clothes for my granddaughters. A little retail therapy was always relaxing." Along with praying and shopping, Lollie suggested that spending time with her granddaughter was also a great way for her to find some peace. Further, she suggested that being there and seeing her granddaughters happy was a way to brighten up a bad day.

Mama Tude (P3) had some of the most unique coping mechanisms of all of the respondents. Given her thirty-year experience with the piano, that was one way in which 
she chose to cope. "The piano sits in the front of my house, and when I sit at my piano, the whole house knows to shut it down cause I've had day." It could be assumed that she also wrote music, because she said that writing was also a way that she coped. However, she did not specify whether it was writing in the sense of journaling or writing music to play on her piano. Mama Tude also road tripped with a friend when times were tough. "I had this one friend, she would call me, and we would just take a road trip, just driving. We would stop, get little hotel room, and then keep on driving."

Dottie (P1) explained that she rarely felt overwhelmed with her responsibilities as a mother and grandmother because she could always talk things over with her mother and husband. 'I'd let it all out to one of them, and things would get better. Things would be alright." However, one has to query how she copes currently, given that her mother and husband have both transitioned. She did suggest an open line of communication with her children and grandchildren, so maybe that could also be a form of coping for her. 


\section{CHAPTER 6: SUMMARY, DISCUSSION \& CONCLUSION}

The findings from the interviews conducted with the six grandmothers reveal stories that corroborate with that of the literatures on the role of women in African American families as well as that of the Black matriarch. Interestingly, the current roles and responsibilities of the grandmothers were quite similar to that of their own mothers and grandmothers, as well as some of the historical roles that black women played in white and black families under slavery and Jim Crow as discussed by Sewell. This includes giving economic, social, cultural and financial support to the core family, the extended family and to a network of other women and children in the African American community.

Interestingly, the grandmothers adopted communication mechanisms that closely resembles that practiced in African Cultures. For example, communications with their grandchildren involved story- telling much like the African oral tradition (LittlejohnBlake \& Darling, 1993). As Jimenez (2002) discussed, story-telling was reported as a tradition passed on from one female generation to another. It is used to impart: (i) cultural histories of the families and African American communities; and (ii) values thought to be important for moral, social and survival strategies. The grandmothers also used story-telling to mentor their grandchildren and other extended families, stressing pursuit of education and encouragement to achieve goals, personal aspirations and dreams. 
Another strategy used by the grandmothers that bears some similarity to the African tradition as well as the African American family tradition is the practice of fictive kinship, which was also addressed by Jimenez. This included embracing and taking care of members of extended family, particularly children (step-children, nieces, nephews, etc.), the elderly (parents and grandparents), as well as other women (aunties, sisters), women in their church and community (adopted aunties). The examples cited by the women personified the popular African saying that 'it takes a village to raise a child.'

\section{The Strong Black Matriarch}

The role and responsibilities of the grandmothers centered on taking care of families which had been discussed in the prior literature by Gibson (2005). The women described the many difficulties and challenges that are involved with this task, particularly for those who identified as working families headed by women who had high school education but not college graduates. The fact that the Black women continue to accept the economic and social responsibilities of helping two generation of families indicates their tenacity and commitment, further supporting the idea of a strong Black woman - matriarch. It is a responsibility that many of the women described as difficult but nevertheless a loving task. According to one of the grandmother "You don't live life for yourself."

Certain indicators or characteristics of what constitutes a strong Black matriarch was discerned from sifting through the six interviews. These include: (i) surviving history and racism, economic hardship and sexism within and external to the home; (ii) having wisdom gained from experience and from guidance and knowledge passed on to them from other women; (iii) being a mentor that involves advising, imparting 
knowledge and values, and also listening (seen as a strength); (iv) dedication to the family and being dependable especially for the grandchildren; (v) overcoming challenges for the sake of the family.

The grandmothers acknowledge that they were aware of the image or idea of the strong Black woman or matriarch, however, did not think before the interview what this meant for them. That is, how this image impacted what was expected of them as Black matriarchs. They were, however, aware that they were expected to have 'super powers' and that their grandchildren believed that "mama is gonna and can fix it....so I have to." This is a reflection of the expectations placed black women as described by BeauboeufLafontant (2009). In the same vein, one of the grandmothers was told by her mother, “don't let nothing stop you, if you can't do it find a way to get it done."

The interviews revealed that Black women are socialized by their own female lineage to accepting the role of the strong Black woman, as a mean of self-survival and ensuring the well-being of families. Nevertheless, unlike the much of the literature that stretches the characteristic of the strength of Black women from super women to nonhuman, the grandmothers spoke about what it was like to carry this weight of being a strong woman in families that faced several socio-economic and racial barriers.

\section{Social and Psychological Stresses \& Coping Mechanisms}

The grandmothers in the study commonly described the social and psychological stresses in their lives in terms of the sacrifices that they made and the sufferings that they encountered. They did not reveal what these were but consistently linked managing stress "to make sure that the family is well." Similar to the idea of linked lives as described by Stack and Burton, because their life choices are affected by their family's 
choices and vice versa. It was indeed sad when one of the grandmothers signed that, "we live for everybody else, maybe we can get to enjoy life one day." The grandmother was not complaining, but simply stating a wish.

Another common feature observed by most of the six grandmothers was that the social and psychological stresses of the women were often untreated, unnoticed and hidden. Ironically, while the women admitted that they were the dependable ones in the families, all but one reported that they did not have anyone to depend on. They also admitted to sometimes having fears and doubts about whether they can stay strong and carry the burden of the family well-being successfully.

Remarkably, the women linked having to hide their social and psychological emotions because of the need to appear strong. They "suffer in silence" and "hide and cry" so as not to seem weak. Very similar to the silence paradigm as described by Beauboeuf-Lafontat (2007). They also manage their stress and sacrifice certain aspects of their lives including finances, time, personal social activities, work and educational opportunities, among others because they see this as part of being a mother or grandmothers. They console themselves by thinking that they do these things because of love....so it is not really a sacrifice.

To overcome stressful feelings, many of the women turn to "the Lord." They also suggest that you must, "pull out before your own sorrow gets you." Other coping strategies included crying, talking to one self, taking or spending time with a girlfriend, mother or husband, interacting with the grandchildren, and treating oneself (e.g. shopping). They also suggested that a good strategy was to always learn from a difficult situation so as not to repeat a problem. 
In sum, the women of the study did not in the beginning of their roles as

grandmothers see themselves as a strong Black matriarch, but as becoming one. They got caught up in a role where they always have to be the 'bigger' person. The grandmothers were also aware, and oftentimes made references to, similar experiences of other Black grandmothers and the need for them to speak-up and be competent.

\section{Black Feminist Perspective}

This study adopted the black feminist perspective as a way of allowing black women, specifically black matriarchs, an opportunity to share their experiences. The experiences and perspectives shared by the six grandmothers are reflective of the core tenets of the black feminist perspective, in that, while the women are very visible in the family and extended family - their roles remain undervalued and unnoticed and the wider society. Black women do not feel empowered outside of the home, despite the central roles in the family.

Secondly, their experiences and perspectives are based on the intersectionality of their race, social class, and gender. The findings of this research yields that despite all the barriers and hardships that black women have faced historically and contemporarily, the grandmothers in the study resisted oppression in order to protect and sustain themselves and their families.

\section{Reflections}

This has been a very fulfilling study for me, as I garnered interest in such a topic after losing one of my grandmothers in November 2016, while my other grandmother had also been diagnosed with ovarian cancer in October 2016 and transitioned February 2018. Given geographical my distance from my grandmothers, I realized that so much I had not 
gotten to ask them, or even thank them for being there for myself and others. Thus, I felt that magnifying the experiences of African American grandmothers would be a great way to gain insight into the general experiences of black grandmothers, as well as a way to pay homage to all that grandmothers do to sustain our families.

Given that some of the grandmothers knew me, and my grandmothers personally, it was interesting to notice how it seemed as if some of the participants were trying to overcompensate for similar experiences or lessons that they knew my own grandmothers had taught me. Some of the participants, along with my mother, grandmothers and aunties were very influential to my upbringing. Thus, in some of the instances where they discussed lessons they taught, or interactions with extended and fictive kin, myself and my family were a part of those experiences. A number of the women participants have cooked for me and kept me as a child. On the other hand, some of the participants that I met through sampling have adopted me as granddaughter.

I am very appreciative of my grandmothers and the legacy of love, patience, and strength that they left behind for me. Moreover, that this influence was strong enough to encourage me to conduct scientific research on the socio-psychological experiences of African American grandmothers. Last, I am grateful for all of the participants and their willingness to be a part of my study, as well as the love and support they all wished me after the interviews were complete.

\section{Future Research}

The interviews focused primarily on the women's experiences in the family and what it was like to be a Black matriarch. Future research is important on how the women negotiate their intersectionality outside of the home. What were their experiences 
confronting racism, classism, sexism and other social factors in the wider society? How did society treat them because of the stereotype of the strong Black woman? What lessons do they pass on to their grandchildren and other members of their fictive kin on how to navigate structures and ideologies of white privilege and white superiority? Additionally, this research only scratched the surface in regard to the sociopsychological experiences of black mother and grandmothers. Thus, further research is needed that would tease out the social and psychological effects of black women in the family. Though the participants addressed their social and psychological experiences within the family, they did not go into very much detail. Thus, a more detailed study of the socio-psychological experiences of African American grandmothers should be studied further. 


\section{REFERENCES}

Barriteau, V. E. (2008). The Relevance of Black Feminist Scholarship. In S. M. James, F. S. Foster \& B. Guy-Sheftall (Eds.), Still Brave, The Evolution of Black Women's Studies. New York: The Feminist Press.

Baydar, N., \& Brooks-Gunn, J. (1998). Profiles of Grandmothers Who Help Care for Their Grandchildren in the United States. Family Relations, 47(4), 385-393. doi: $10.2307 / 5852692$

Beauboeuf-Lafontant, T. (2007) "You have to show strength: An exploration of gender, race, and depression." (Gender \& Society)

Beauboeuf-Lafontant, T. (2009) Behind the Mask of the Strong Black Woman: Voice and Embodiment of a Costly Performance. Philadelphia, PA: Temple University Press.

Beoku-Betts, J., \& Njambi, N. W. (2004). African Feminist Scholars in Women's Studies, Negotiating Spaces of Dislocation in the Study of Women. In S. M. James, F. S. Foster \& B. Guy-Sheftall (Eds.), Still Brave, the Evolution of Black Women's Studies. New York: The Feminist Press.

Billingsely, A. (1968). Black Families in White America. Ann Arbor, MI: Simon \& Schuster

Burgess, N. J. (1995). Female-headed households in sociohistorical perspective. In B. J. Dickeron, African american single mothers: understanding their lives and families. (21-36). Thousand Oaks, CA: SAGE Publications

Burton, L. M. (1996). Age norms, the timing of family role transitions, and intergenerational caregiving among aging African American women. The Gerontologist, 36(2), 199-208.

Caraway, N. (1991). Segregated Sisterhood: Radsm and the Politics of American Feminism. Knoxville: University of Tennessee Press.

Chavan, Sampada. "Natural Woman, Unnatural Mother: The Convergence of Motherhood and the "Natural" World in Alice Walker's Meridian." Journal of 
International Women's Studies 16.2 (2015): 188-99. ProQuest. Web. 30 Oct. 2017.

Cho, S., Crenshaw, K., \& McCall, L. (2013). Toward a Field of Intersectionality Studies: Theory, Applications, and Praxis. Signs,38(4), 785-810. doi:10.1086/669608

Cleage, P. (1993). Deals With the Devil and Other Reasons to Riot. New York: Ballantine Books.

Collins, P. (1986). Learning from the Outsider Within: The Sociological Significance of Black Feminist Thought. Social Problems, 33(6), S14-S32. doi:10.2307/800672

Collins, P. (1990). Black feminist thought: Knowledge, consciousness, and the politics of empowerment. New York: Routledge

Collins, P. (1996). WHAT'S IN A NAME? Womanism, Black Feminism, and Beyond. The Black Scholar, 26(1), 9-17.

Collins, P. (2012). Social Inequality, Power, and Politics: Intersectionality and American Pragmatism in Dialogue. The Journal of Speculative Philosophy, 26(2), 442-457. doi:10.5325/jspecphil.26.2.0442

Crenshaw, K. W. (1989). Demarginalizing the intersection of race and sex: A black feminist critique of antidiscrimination doctrine, feminist theory and antiracist politics. University of Chicago Legal Forum. 139. (5,6).

Crenshaw, K. W. (1991) Mapping the margins: intersectionality, Identity politics, and violence against women of color. Stanford Law Review 43(6): 1241-99.

Cresswell, J. W. (2009). Research Design: Qualitative, Quantitative, and Mixed Methods Approaches. Thousand Oaks, CA: Sage Publications.

Dandekar, Hemalata C. "QUALITATIVE METHODS IN PLANNING RESEARCH AND PRACTICE.” Journal of Architectural and Planning Research, vol. 22, no. 2, 2005, pp. 129-137.

Davis, A. (1971) Reflection on the Black Woman's Role in the Community of slaves. Black Scholar, 2(6), 2-15.

Davis, A. (1981) Women, Race and Class. (New York, NY: Random House

Dickerson, B. J., (1995). African American single mothers: Understanding their lives and families. Thousand Oaks, CA: SAGE Publications.

Dobbins, M. P., \& Mulligan, J. (1980). Black Matriarchy: Transforming a Myth of Racism into a Class Model. Journal Of Comparative Family Studies, 11(2), 195217. 
Enke, A. (2003). Smuggling Sex through the Gates: Race, Sexuality, and the Politics of Space in Second Wave Feminism. American Quarterly, 55(4), 635-667.

Farrar, T. (1997). The Queenmother, Matriarchy, and the Question of Female Political Authority in Precolonial West African Monarchy. Journal of Black Studies, 27(5), 579-597.

Foster, H. (1983). African patterns in the afro-american family. Journal of Black Studies, 14(2), 201-232

Franklin, D. L., James, A. D., (2015). Ensuring Inequality: The structural transformation of the African-American family. New York: Oxford University Press.

Gibson, P. (2005). Intergenerational Parenting From the Perspective of African American Grandmothers. Family Relations, 54(2), 280-297.

Gordon, L. (2013). Socialist Feminism: The Legacy of the "Second Wave". New Labor Forum, 22(3), 20-28.

Harding, S. (2009). Standpoint Theories: Productively Controversial. Hypatia, 24(4), 192-200.

Harnois, C. (2010). Race, Gender, and the Black Women's Standpoint. Sociological Forum, 25(1), 68-85.

Harvey, I., Johnson, L., \& Heath, C. (2013). Womanism, Spirituality, and Self-Health Management Behaviors of African American Older Women. Women, Gender, and Families of Color, 1(1), 59-84. doi:10.5406/womgenfamcol.1.1.0059

Henderson, C. (2013). Sympathetic Violence: Maria Stewart's Antebellum Vision of African American Resistance. MELUS, 38(4), 52-75.

hooks, B. (2000). Black Women: Shaping Feminist Theory. In J. James \& D. T. Sharpley-Whiting (Eds.), The Black Feminist Theory. Malden: Blackwell Publishers.

Hubbard, L. (2010). Anna Julia Cooper and Africana Womanism: Some Early Conceptual Contributions. Black Women, Gender Families, 4(2), 31-53. doi:10.5406/blacwomegendfami.4.2.0031

Hyman, H. H., \& Reed, J. S. (1969). 'Black matriarchy' reconsidered: Evidence from secondary analysis of sample surveys. Public Opinion Quarterly, 33(3), 346-354. doi: $10.1086 / 267718$

Jewell, K. S. (2003) Survival of the African American Family: The Institutional Impact of U.S. Social Policy. Westport, CT: Praeger Publishers. 
Jimenez, J. (2002). The History of Grandmothers in the African-American Community. Social Service Review, 76(4), 523-551. doi:10.1086/342994

Johnson-Bailey, J. (2003). Everyday Perspectives on Feminism: African American Women Speak Out. Race, Gender \& Class, 10(3), 82-99.

Kelley, S. J., Whitley, D. M., \& Campos, P. E. (2013). Psychological distress in African American grandmothers raising grandchildren: The contribution of child behavior problems, physical health, and family resources. Research In Nursing \& Health, 36(4), 373-385. doi:10.1002/nur.21542

Littlejohn-Blake, S., \& Darling, C. (1993). Understanding the strengths of african american families. Journal of Black Studies, 23(4), 460-471

Lorde, A. (1995). Age, Race, Class, and Sex: Women Redefining Difference. In B. GuySheftall (Ed.), Word of Fire: An Anthology of African-American Feminist Thought. New York: The New Press.

McAdoo, H. P. (1998). African american families: Strength and realities. In H. I. McCubbin, E. A. Thomas, A. I. Thomas, \& J. A. Futrell (Eds.), Resiliency in african-american families. (17-30). Thousand Oaks, CA: SAGE Publications.

Morgan, J.-A. (Spring 1995). Mammy the huckster: Selling the old South for the new century. American Art, 9(1), 86-109

Noy, C. (2008). Sampling knowledge: The hermeneutics of snowball sampling in qualitative research. International Journal of Social Research Methodology, 11, 327-344.

Ochiai, A. (1992). IDA B. WELLS AND HER CRUSADE FOR JUSTICE: An African American Woman's Testimonial Autobiography. Soundings: An Interdisciplinary Journal, 75(2/3), 365-381. Retrieved from http://www.jstor.org/stable/41178581

Omolade, B. (1994). The Rising Song of African American Women. New York: Routledge

Parkhurst, J. (1938). The Role of the Black Mammy in the Plantation Household. The Journal of Negro History, 23(3), 349-369. doi:10.2307/2714687

Richardson, M. (1987). Maria W. Stewart, America's First Black Woman Political Writer. Bloomington: Indiana University Press.

Rolin, K. (2009). Standpoint Theory as a Methodology for the Study of Power Relations. Hypatia, 24(4), 218-226. 
Ross, M., \& Aday, L. (2006). Stress and coping in African American grandparents who are raising their grandchildren. Journal Of Family Issues, 27(7), 912-932.

Roth, B. (2004). Separate Roads to Feminism: Black, Chicana, and White Feminist Movements in America's Second Wave. New York: Cambridge University Press.

Rousseau, N. (2013). Historical Womanist Theory: Re-Visioning Black Feminist Thought. Race, Gender \& Class, 20(3/4), 191-204

Sewell, C. (2013). Mammies and Matriarchs: Tracing Images of the Black Female in Popular Culture 1950s to Present. Journal of African American Studies, 17(3), 308-326.

Shamase, M. Z. (2017). A THEORETICAL EXPOSITION OF FEMINISM AMD WOMANISM IN AFRICAN CONTEXT. Gender \& Behaviour, 15(2), 92109222.

Shambley-Ebron, D. Z., \& Joyceen S. B. "New Paradigms for Transcultural Nursing: Frameworks for Studying African American Women.” Journal of Transcultural Nursing 15, no. 1 (2004): 11-17

Silverman, D. (1997). Qualitative Research: Theory, Method, and Practice. Thousand Oaks, CA: Sage Publications.

Simms, R. (2001). Controlling Images and the Gender Construction of Enslaved African Women. Gender and Society, 15(6), 879-897.

Smith, B. (1995). Some Home Truths on the Contemporary Black Feminist Movement. In B. Guy-Sheftall (Ed.), Words of Fire: An Anthology of African-American Thought. New York: The New Press.

Smith, C. (1998). PRAGMATISM AND WOMANIST THEOLOGY: INTERPRETIVE POSSIBILITIES. American Journal of Theology \& Philosophy, 19(2), 209-223.

Smith, G. C., Cichy, K. E., \& Montoro-Rodriguez, J. (2015). Impact of Coping Resources on the Well-Being of Custodial Grandmothers and Grandchildren. Family Relations, 64(3), 378-392.

Smith, G. C., Palmieri, P. A., Hancock, G. R., \& Richardson, R. A. (2008). Custodial Grandmothers' Psychological Distress, Dysfunctional Parenting, and Grandchildren's Adjustment. International Journal Of Aging And Human Development, 67(4), 327-357.

Stack, C. B., \& Burton, L. M. (1993). Kinscripts. Journal of Comparative Family Studies, $157-170$ 
Staples, R. (1981). The Myth of the Black Matriarchy. The Black Scholar, 12(6), 26-34.

The Combahee River Collective. (2014). A Black Feminist Statement. Women's Studies Quarterly, 42(3/4), 271-280.

Timberlake, E., \& Chipungu, S. (1992). Grandmotherhood: Contemporary Meaning among African American Middle-Class Grandmothers. Social Work, 37(3), 216222.

Walby, S., Armstrong, J., \& Strid, S. (2012). Intersectionality: Multiple Inequalities in Social Theory. Sociology,46(2), 224-240.

Walker, A. (1983). In Search of Our Mothers' Gardens. New York: Harcourt, Brace Jovanovich

Walkington, L. (2017). How Far Have We Really Come? Black Women Faculty and Graduate Students' Experiences in Higher Education. Humboldt Journal of Social Relations, 39, 51-65.

Waters, J. (2015). Snowball sampling: a cautionary tale involving a study of older drug users. International Journal Of Social Research Methodology, 18(4), 367-380. doi: $10.1080 / 13645579.2014 .953316$

Watson, J., \& Koblinsky, S. (2000). Strengths and Needs of African American and European American Grandmothers in the Working and Middle Classes. The Journal of Negro Education, 69(3), 199-214. doi:10.2307/2696232

Willie, C. V. \& Reddick, R.J. (2010). A new look at black families. Lanham, MA: Rowman \& Littlefield Publishers

Wylie, A. (2012). Feminist Philosophy of Science: Standpoint Matters. Proceedings and Addresses of the American Philosophical Association, 86(2), 47-76. 


\section{CURRICULLUM VITA}

\section{Tanisha N. Stanford}

\section{Contact Information}

Department of Pan-African Studies

University of Louisville

445 Strickler Hall

Louisville, Kentucky 40292

Department phone: 502-852-5985
2501 S. $4^{\text {th }}$ Street

Louisville, Kentucky 40208 469-544-0183 (cell)

tanisha.stanford@louisville.edu

tnstanford12@gmail.com

\section{Research Interests}

Current research interests include the experiences and influences of the African American grandmother within the family and community. I'm also interested grandparents that have custodial parenting roles over their grandchildren, and the experiences of these children. Further, I would be interested in other forms of youth development as well as developing community-based youth programs and organizations.

\section{Education}

University of Louisville, Louisville, Kentucky

2016-Present

Master of Arts, Pan-African Studies

Emphasis Areas: African American Experience

Master Thesis: “African American Grandmothers as Black Matriarchs: You Don't Live for Yourself"

GPA: 3.811

University of Houston, Houston, Texas

2012-2016

Bachelor of Science, Psychology; minor in African American Studies

Capstone Thesis: "Critical Analysis of the Mental Health Controversy within the Black Community"

\section{Research Experience}

University of Louisville (Department of Pan-African Studies) 
Co-Principal Investigator for 'Let Justice Roll Down Like Waters': The Role of Spirituality in African American Environmental Activism in the U.S. South"

- $\quad$ Assisted in completion of NEH and Antipode grant applications

- $\quad$ Assisted in conference preparation

- Lead conference operations

- Conference website design and social media

$\circ \quad$ Conference logistics and budgeting

- Correspondence with conference participants

- $\quad$ Assisted with research publication

Co-Investigator for Jan Carew Archival History Project (Will be donated to the University of Louisville's Ekstrom Library in 2018) 2016- Present

- Database creation

- $\quad$ Cataloguing, labeling and books, visual and audio media to the database — both physically and electronically

Workshop luncheon- "Uncomfortable Lunch" Fall 2017

- Workshop operations

- Correspondence with workshop participants

Graduate Grant Writing Academy

- Developed knowledge and skills in grant writing.

\section{Instructional Experience}

Guest Lectures:

PAS 305: Legal Lynchings: Survey of Race, Law and American Justice System

(Student Count: 18)

Spring 2017

PAS 200: Introduction to Pan African Studies

Fall 2017

(Student Count: 25)

HON 331: The World that Africa Made [Honors course] Spring 2018

(Student Count: 28)

HIST 364: Russian History

(Student Count: 11)

\section{Community Experience}

Girls League of the West (G.L.O.W.)

2017-Present

- $\quad$ College preparation and networking panel

- $\quad$ Mentorship workshop

- $\quad$ Passion and Purpose Workshop

Pan-African Studies Undergraduate Capstone Panel Spring 2017

- $\quad$ Aid undergraduate students in preparing for and applying for graduate schools.

Academic Mentoring Program for Education and Development (AMPED)

2015-2016

- Motivates students to pursue success in school and life

- $\quad$ Equip students with skills that enable academic success 
- $\quad$ Support students as they create and pursue specific goals in school

- $\quad$ After school mentorship and tutoring in a stimulating learning environment

- $\quad$ Skill-building, character building and dream building

- Aid in nurturing children to gain enhancing self-esteem, while supporting emotional and intellectual growth

\section{Awards and Recognitions}

Antipode International Workshop Award

- 2016/2017 recipient for the purpose of funding "Let Justice Roll

Down Like Water: The role of Spirituality in African American

Environmental Activism in the U.S. South" Conference hosted at the University of Louisville in Spring 2018.

Dr. Kwame Nkruma International Studies Scholar 2016

- 2016 recipient international scholarship to study abroad in Ghana, West Africa.

Pan-African Studies Graduate Assistantship

Graduate Dean's Citation

2016-Present 2018

\section{Organizations}

GNAS: Graduate student network for Arts and Science - Pan-African Studies representative 2016-Present PGSA: Pan African Studies graduate studies association - Social media chair and secretary

2016- Present

\section{Other Skills}

Computer: Microsoft Office, SPSS (Statistical Program) 